\title{
ЭТАПЫ ЭВОЛЮЦИИ И ПЕТРОЛОГИЯ КЕКУКНАЙСКОГО ВУЛКАНИЧЕСКОГО МАССИВА КАК ОТРАЖЕНИЕ МАГМАТИЗМА ТЫЛОВОЙ ЗОНЫ КУРИЛО-КАМЧАТСКОЙ ОСТРОВОДУЖНОЙ СИСТЕМЫ. ЧАСТЬ 2. ПЕТРОЛОГО-МИНЕРАЛОГИЧЕСКИЕ ОСОБЕННОСТИ, МОДЕЛЬ ПЕТРОГЕНЕЗИСА
}

\author{
(C) 2013 г. А. В. Колосков ${ }^{1}$, Г. Б. Флеров ${ }^{1}$, А. Б. Перепелов ${ }^{2}$, И. В. Мелекесцев ${ }^{1}$, \\ М. Ю. Пузанков ${ }^{1}$, Т. М. Философова ${ }^{1}$ \\ ${ }^{1}$ Институт вулканологии и сейсмологии ДВО РАН \\ 683006 Петропавловск-Камчатский, бульвар Пийпа, 9, \\ e-mail: kolosav@kscnet.ru \\ ${ }^{2}$ Институт геохимии им. А.П. Виноградова СО РАН \\ 664033 Иркутск, ул. Фаворского, 1А, \\ e-mail: region@igc.irk.ru \\ Поступила в редакцию 20.03.2012 г.
}

\begin{abstract}
Кекукнайский массив сформировался в результате тектоно-магматической деятельности, выразившейся образованием щитообразного вулкана, кальдерной депрессии с сопутствующим внедрением экструзий, и завершившейся интенсивным посткальдерным ареальным вулканизмом. Проведено детальное рассмотрение особенностей минералогического состава пород массива. Использование уже имеющихся и дополнительно выявленных индикаторных возможностей породообразующих минералов позволило восстановить общую картину эволюции магматических расплавов и условия кристаллизации пород (различная флюидонасыщенность-обводненность и окисленность системы). Существенно островодужные или внутриплитные характеристики в составе пород массива проявлены на разных стадиях развития единой флюидно-магматической системы. Декомпрессионная эволюция материнской глубинной базанитовой магмы была реализована появлением в промежуточных очагах дочерних магм трахибазальтового (докальдерный этап развития системы) или гавайитового (ареальный вулканизм) состава. Дальнейшая эманационно-магматическая дифференциация этих расплавов в сочетании с кристаллизационной дифференциации в условиях меняющейся Р-Т-f $\mathrm{O}_{2}$ обстановки и привела к образованию всего многообразия пород Кекукнайского массива.
\end{abstract}

DOI: $10.7868 / \mathrm{S} 0203030613020053$

\section{ВВЕДЕНИЕ}

Кекукнайский вулканический массив - сложно построенное геологическое сооружение, образовавшееся в результате многостадийной эволюции флюидно-магматической системы с конца верхнего плиоцена и во время всего четвертичного периода. Длительность проявления вулканизма, наличие в его пределах контрастных типов пород - благодатная обстановка для решения многих вопросов соотношения вулканизма и геодинамики.

В первой части статьи [Колосков и др., 2011] было сделано детальное описание геологического строения Кекукнайского массива, приведены данные о петрохимическом, геохимическом, а также изотопном составе пород массива.
Кекукнайский массив сформировался в результате тектоно-магматической деятельности, выразившейся образованием щитообразного вулкана, кальдерной депрессии с сопутствующим внедрением экструзий, и завершившейся интенсивным посткальдерным ареальным вулканизмом. По геохимическим данным в составе массива выделены островодужный и внутриплитный геохимические типы пород как отражение конструктивного, а затем деструктивного этапов развития региона. Становление массива происходило в обстановке открытой системы, поэтому главную роль в процессах петрогенеза играла динамика флюидной фазы при подчиненной роли фракционной кристаллизации и процессов гибридизма.

В предлагаемой второй части статьи мы постараемся выяснить, как эти процессы отразились в 
минеральном облике составов пород и попробуем подойти к созданию обобщающей петрологической модели.

Обычное петрографическое изучение пород дополнялось анализом составов минералов с помощью рентгеноспектрального микроанализатора "САМЕВАХ" в ИВиС ДВО РАН (с обычной точностью анализа - для макрокомпонентов около $0.1 \%$ и для малых содержаний - около 10\%). Так как породы в основном представлены афировыми и субафировыми разностями, то исследования проводились не только в шлифах и аншлифах, но и в мономинеральных шашках искусственных шлихов с размером зерен более 0.25 мм.

\section{ПЕТРОГРАФИЯ И МИНЕРАЛОГИЯ ПОРОД КЕКУКНАЙСКОГО МАССИВА}

\section{Характер распространения различных типов пород, петролого-геохимические ассоциации}

В данной статье в составе массива рассматриваются следующие ассоциации пород (рис. 1, табл. 1).

I. Трахибазальт-трахидацитовая, отражающая состав пород докальдерной постройки щитообразного вулкана и экструзий этапа кальдерообразования.

\section{II. Трахибазальтовая и}

III. Андезибазальтовая шлаковых конусов ранней стадии ареального вулканизма.

IV. Гавайит-андезибазальтовая (муджиеритовая) средней стадии ареального вулканизма.

V. Трахибазальт-гавайит-андезибазальтовая (муджиеритовая) поздней стадии ареального вулканизма.

Состав пород этих ассоциаций в виде полей и фигуративных точек показан на различных петро-геохимических диаграммах (рис. 2). Наиболее индивидуализированы составы полей I и IV accoциаций (см. рис. 2a). Породы I ассоциации характеризуются пониженными концентрациями $\mathrm{Nb}$ и образуют обособленное поле с трендом прямой корреляционной зависимости $\mathrm{Nb}-\mathrm{K}$, что является характерным признаком островодужных (орогенных) вулканитов. Составы пород IV ассоциации полностью отвечают так называемым внутриплитным вулканитам с повышенным содержанием высокозарядных элементов и отсутствием корреляции $\mathrm{Nb}-\mathrm{K}$. Три другие ассоциации отличаются промежуточными между этими двумя типами пород составами. Возникает вопрос, как эти геохимические особенности отражаются в соответствующих петрографических и минералогических характеристиках пород и каковы пути их происхождения.

\section{Структурные характеристики и особенности вещественного состава пород}

В общем случае, породы выделенных ассоциаций заметно отличаются по структурному облику. Если лавам щитообразной постройки и породам экструзий присущи серийно-порфировые и густо-мелкопорфировые структуры, то для ареальных вулканитов характерно субафировое и редкомелкопорфировое строение. В зависимости от фациальной принадлежности (некк, шлак, бомба, лава) и степени кристалличности пород, наблюдаются разнообразные микроструктуры основной массы: от витрофировой и гиалопилитовой до пилотакситовой и микродолеритовой. Принимая во внимание разную степень кристалличности пород, среди которых значительный объем занимают субафировые разности, одним из критериев различия типов вулканитов может служить их нормативный минеральный состав, а показателем условий кристаллизации - отличие модального и нормативного составов (см. табл. 1). Дальнейшее изложение материала и будет построено в основном на сопоставлении нормативных и модальных составов пород, а также сравнении составов минералов Кекукнайского массива с некоторыми типовыми ассоциациями. В качестве таковых будут использованы результаты изучения оливинов [Волынец и др., 1975] и плагиоклазов [Волынец, Колосков, 1976] из различных типов пород (преимущественно известково-щелочного и толеитового состава) четвертичных базальтов Камчатки и Курил. Кроме того, авторы располагают большим аналитическим материалом по составу пород плиоценового Белоголовского вулкана, который при высокой щелочности и широкому диапазону кремнекислотности пород относится к проявлениям внутриплитного геохимического типа [Volynets, 1994].

Появление в нормативном составе кварца отмечено (см. табл. 1) во всех породах повышенной кремнекислотности (начиная с андезибазальтов), тогда как единичные его зерна были отмечены только в некоторых образцах трахибазальтов, муджиеритов и гавайитов. Нефелин в нормативных составах отсутствует в породах докальдерного комплекса, но типичен для ареальных гавайитов и трахибазальтов. В модальном составе фельдшпатоиды встречены не были.

Гиперстен в расчетных составах широко представлен почти во всех разностях пород за исключением гавайитов и трахибазальтов некка (обр. к53). Модальный ортопироксен присутствует в породах щитообразного вулкана, трахиандезитах экструзий, почти всех разностей (за исключением трахибазальтов и муджиеритов) ранней и средней стадий, но отсутствует во всех разностях пород поздней стадии ареального вулканизма. 

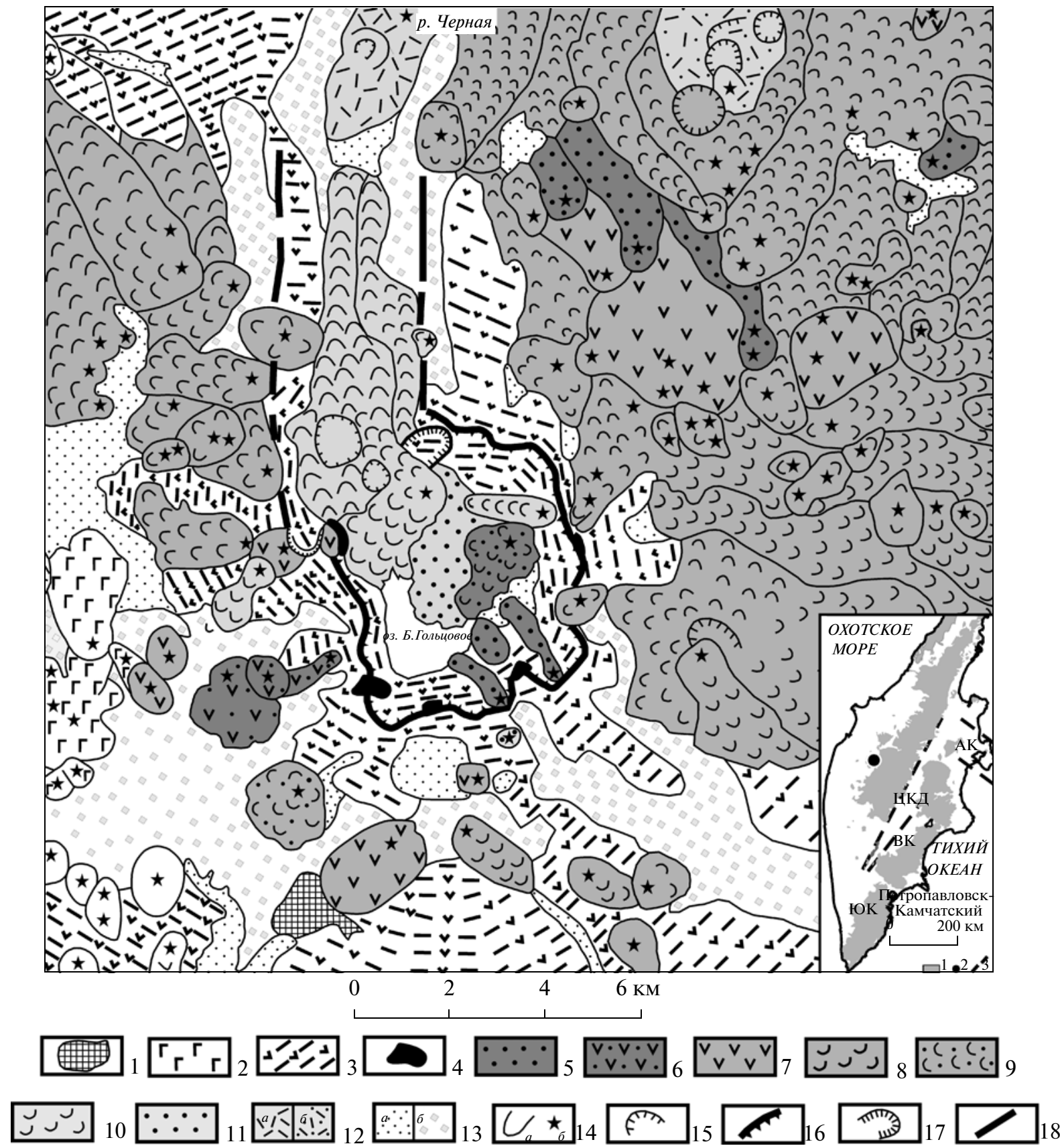

Рис. 1. Схема распределения магматических образований Кекукнайского вулканического массива.

1 - вулканогенные породы фундамента миоцен-плиоценового возраста $\left(\mathrm{N}_{1-2}\right) ; 2$ - гавайиты, андезиты массива горы Большая $\left(\mathrm{Q}_{3}\right)$. Кекукнайский массив: 3 - трахибазальт-трахиандезиты щитообразного вулкана докальдерного этапа $\left(\mathrm{Q}_{1-2}\right) ; 4$ - трахиандезиты, трахидациты экструзий синкальдерного этапа $\left(\mathrm{Q}_{1-2}\right)$ (ассоциация I). Посткальдерный этап $\left(\mathrm{Q}_{3}^{2}-\mathrm{Q}_{4}\right)$. Ранняя стадия: 5 - трахибазальты (ассоциация II); 6 - амфиболовые андезибазальты (ассоциация III). Средняя стадия: 7 - андезибазальты; 8 - породы гавайит-муджиеритового ряда; 9 - породы гавайит-трахибазальт-муджиеритового состава (ассоциация IV). Поздняя стадия: 10 - породы гавайит-муджиеритового ряда; 11 - трахибазальты; 12 - андезибазальты, андезиты (a) и трахириолиты (б) (ассоциация V); 13 - аккумулятивные отложения разного происхождения $\left(Q_{3}^{4}-Q_{4}\right)$ : флювиогляциальные, аллювиальные, озерные и др. $(a)$, морены II-ой фазы позднеплейстоценового оледенения (б); 14 - лавовые потоки ( $a$ ) и эруптивные центры (б); 15 - эксплозивные кратеры, маары, воронки фреатических взрывов на лавовых потоках; 16 - уступ вулкано-тектонической кальдеры; 17 - сбросы, обвалы; 18 предполагаемые тектонические нарушения.

На врезке: положение Кекукнайского вулканического массива в составе вулканических поясов островодужной системы Камчатки.

1 - кайнозойские вулканические пояса Камчатки (CX - Срединного хребта, ЮК - Южной и ВК - Восточной Камчатки); 2 - Кекукнайский вулканический массив; 3 - условные границы Центральной Камчатской депрессии (ЦКД) и структуры Алеутско-Камчатского сочленения (АК). 

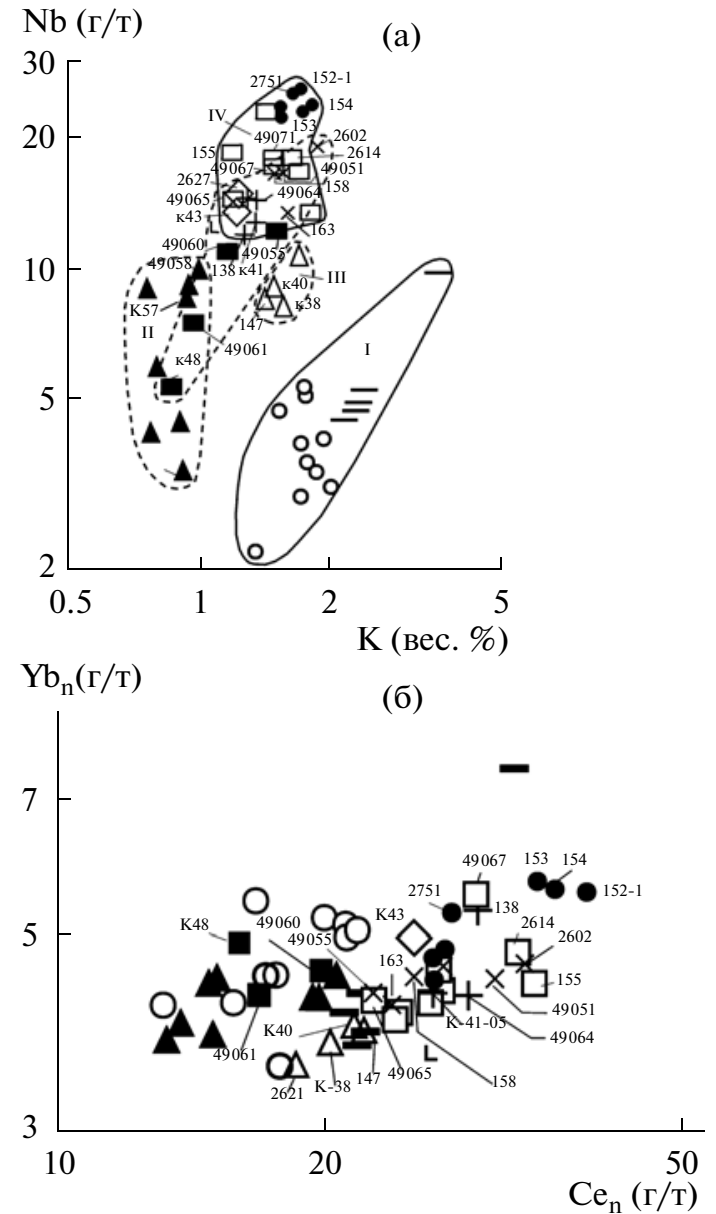

$\mathrm{TiO}_{2}($ Bec. \%)

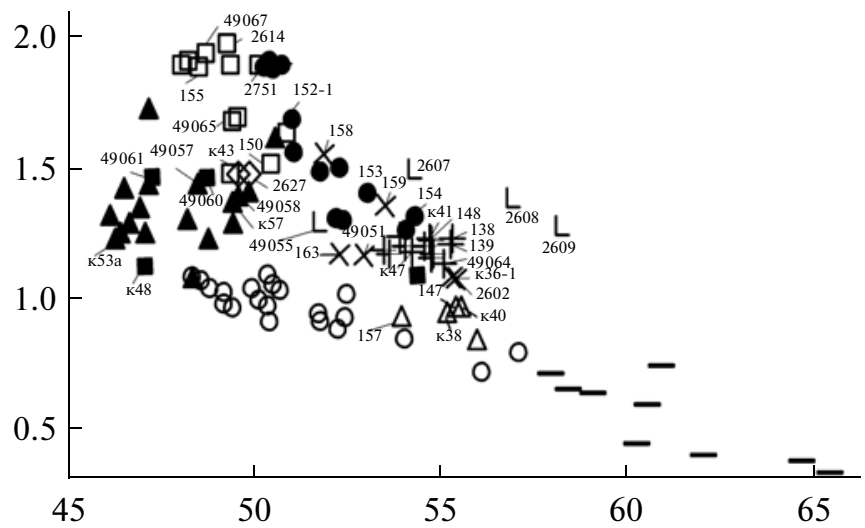

$\mathrm{Na}_{2} \mathrm{O}+\mathrm{K}_{2} \mathrm{O}($ вec. \%)

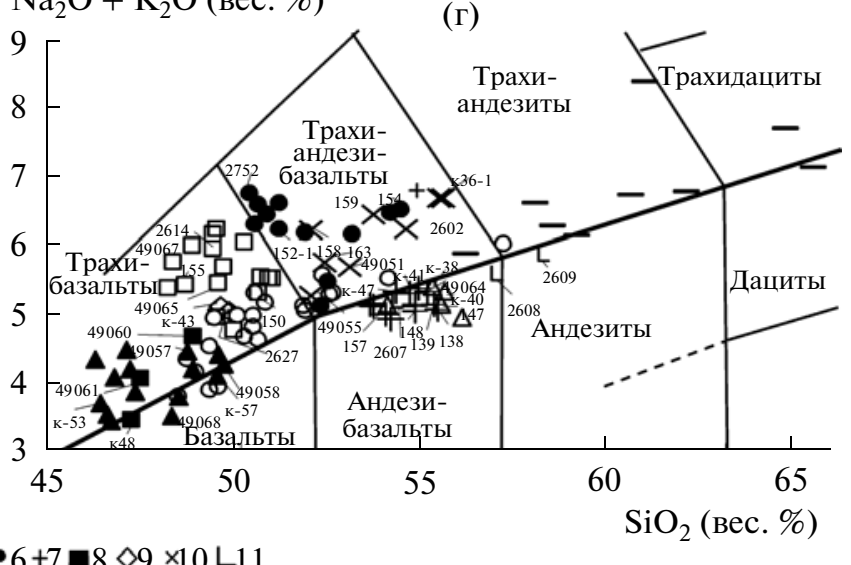

Рис. 2. Диаграмма составов вулканических пород Кекукнайского массива в координатах $\mathrm{Nb}-\mathrm{K}(\mathrm{a}), \mathrm{Yb}_{\mathrm{n}}-\mathrm{Ce}_{\mathrm{n}}\left(\right.$ б), $\mathrm{TiO}_{2}-$ $\mathrm{SiO}_{2}$ (в) и $\mathrm{Na}_{2} \mathrm{O}+\mathrm{K}_{2} \mathrm{O}-\mathrm{SiO}_{2}$ (г).

1-2 - докальдерная стадия и экструзии: 1 - трахибазальты-трахиандезиты постройки щитообразного вулкана, 2 трахиандезиты-трахидациты экструзий; 3-4 - ранняя стадия ареального вулканизма: 3 - трахибазальты, 4 - амфиболовые андезибазальты шлаковых конусов; 5-7 - средняя стадия ареального вулканизма: 5 - гавайиты, 6 - муджиериты, 7 - андезибазальты; 8-11 - поздняя стадия ареального вулканизма: 8 - трахибазальты, 9 - гавайиты, 10 - муджиериты, 11 - андезибазальты. I-V - поля породных ассоциаций (объяснение в тексте). Для А и Б масштаб логарифмический, для В и Г - обычный. Поля составов различных породных групп (Г) даны по [Петрографический кодекс ..., 2009]. Нанесены номера образцов, используемых в тексте.

Нормативный оливин является характерной особенностью пород ареального типа. Но гораздо шире распространен модальный оливин, который встречается также в андезибазальтах ареального типа при отсутствии нормативного эквивалента, правда, в разных количествах.

Резкие отличия для всех разностей пород существуют между модальным и нормативным составами плагиоклаза. Проблема, которая наиболее остро стоит при обосновании номенклатуры гавайитов и муджиеритов (гавайиты - породы с модальным андезином, муджиериты - олигоклазом).

Рассмотрим специфику петрографического состава основных разностей пород массива.
Трахибазальты - трахиандезиты постройки щзитообразного вулкана отличаются повышенной кристалличностью: доля вкрапленников и субфенокристаллов достигает 75 об. \%. По составу вкрапленников трахибазальты представлены ортопироксен-оливин-клинопироксен-плагиоклазовыми разностями с существенным преобладанием полевого шпата. По взаимоотношению минералов отмечается более поздняя кристаллизация клинопироксена относительно оливина и ортопироксена. Для этих пород типичен титаномагнетит (рис. 3), присутствующий во вкрапленниках оливина и пироксенов. Основная масса содержит микролиты тех же минералов, кали-натровый полевой шпат и щелочное стекло в базисе. По мере повышения кремнекислотности пород снижается 
(a)

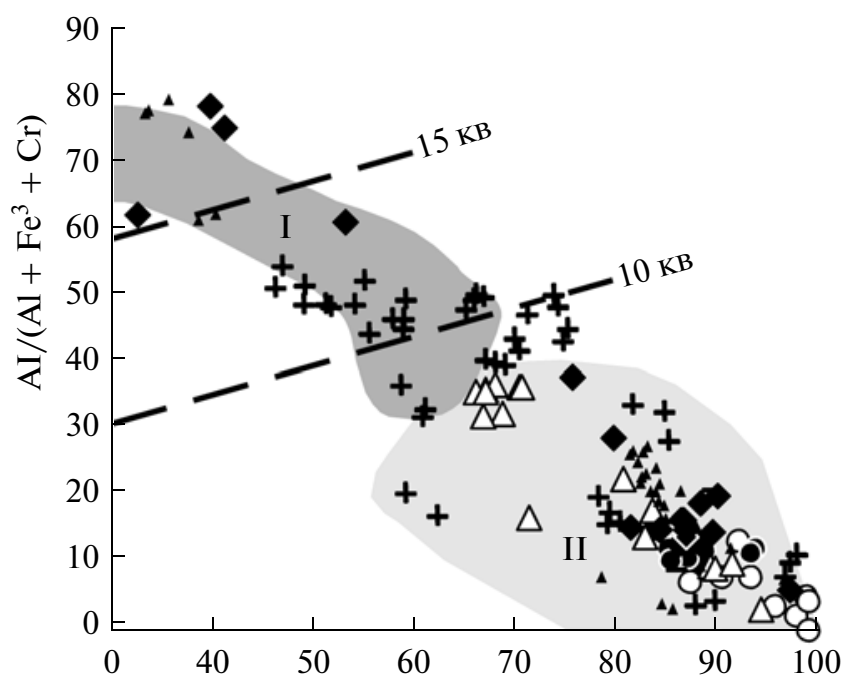

(в)

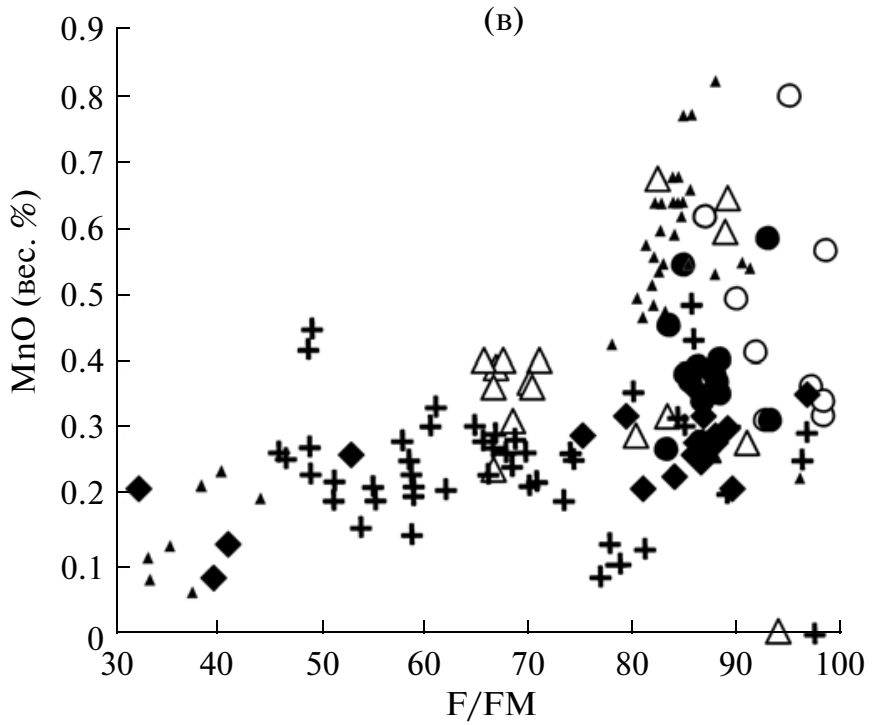

(б)

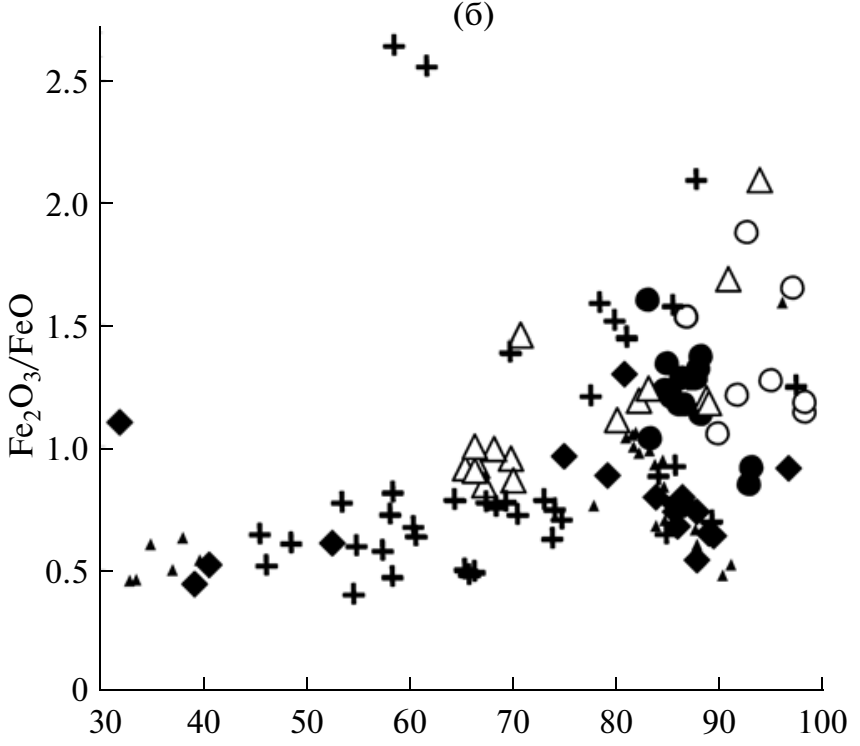

(г)

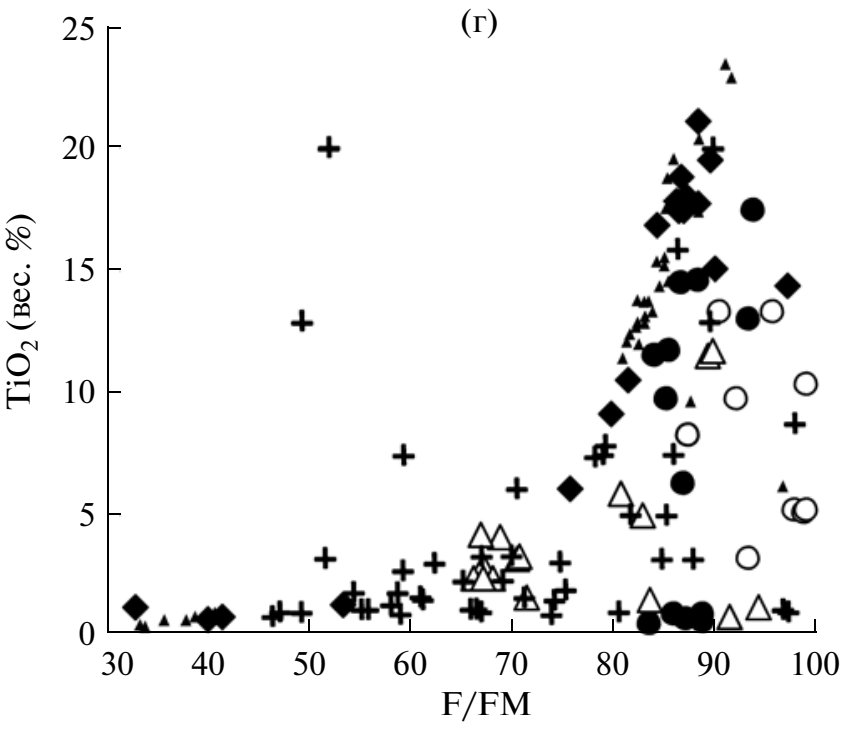

$01 \bullet 2+3 \wedge 45 \bullet 6$

Рис. 3. Диаграмма составов шпинелидов из пород Кекукнайского массива в координатах: $\mathrm{Al} /\left(\mathrm{Al}+\mathrm{Fe}{ }^{3}+\mathrm{Cr}\right)-\mathrm{F} / \mathrm{FM}(\mathrm{a})$, $\mathrm{Fe}_{2} \mathrm{O}_{3} / \mathrm{FeO}-\mathrm{F} / \mathrm{FM}$ (б), $\mathrm{MnO}-\mathrm{F} / \mathrm{FM}$ (в), $\mathrm{TiO}_{2}-\mathrm{F} / \mathrm{FM}$ (г).

1 - трахибазальты докальдерной стадии, андезиты экструзии; 2-3 трахибазальтовая ассоциация ранней стадии ареального вулканизма: 2 - породы некка (обр. к53), 3 - породы потока и шлакового конуса (обр. 49058, к57, к50); 4-5 - средняя стадия ареального вулканизма: 4 - гавайиты, 5 - андезибазальты и муджиериты; 6 - поздняя стадия ареального вулканизма (трахибазальты, андезибазальты, муджиериты). $\mathrm{Al} /\left(\mathrm{Al}+\mathrm{Fe}^{3}+\mathrm{Cr}\right)-$ в атом. количествах, $\mathrm{Fe}_{2} \mathrm{O}_{3} / \mathrm{FeO}$ - в вес. \%, F/FM - железистость ( $\mathrm{Fe} / \mathrm{Fe}+\mathrm{Mg}$ атом. количества). а - выделены поля составов шпинелидов в базальтах “внутриплитного” (I) и островодужного типов (II). Предполагаемые границы полей барофильности, по [Колосков и др. 2001].

количество оливина в трахиандезибазальтах, вплоть до его отсутствия в трахиандезитах. Магнезиальность оливина вкрапленников изменяется от $\mathrm{Fo}_{84}$ до $\mathrm{Fo}_{63}$, причем составы со значением $\mathrm{Fo}_{83-79}$ образуют обособленную группу (рис. 4, обр. 144, 141), которая не укладывается в общую полосу зависимости наиболее ранних генераций оливина от магнезиальности вмещающей породы. На диа- грамме MnO-Fo (рис. 5a) только незначительная часть наиболее магнезиальных генераций попадает в поле составов известково-щелочных серий и отвечает тренду нормальной кристаллизационной дифференциации. Для большей части составов с уменьшением магнезиальности оливинов, росту щелочности и флюидонасыщенности пород наблюдается возрастание содержания мар- 


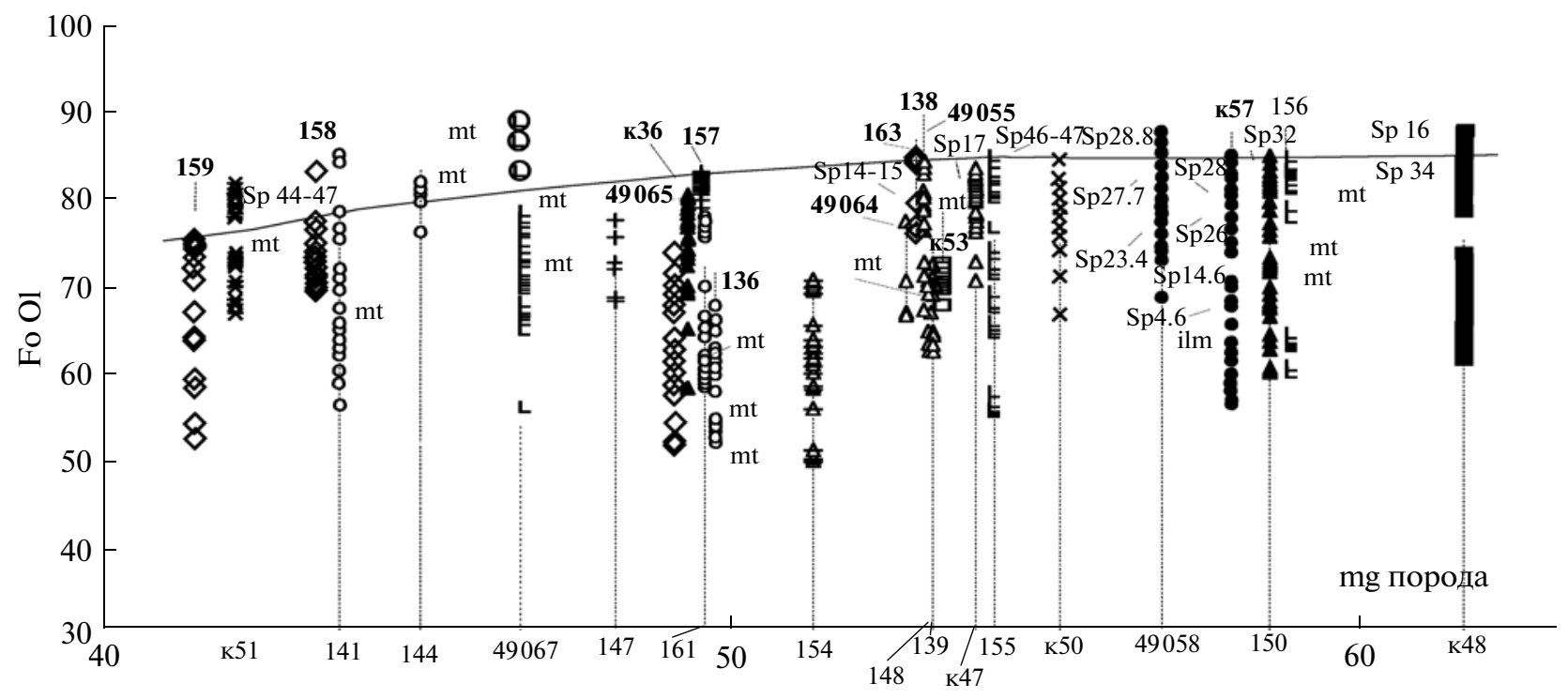

○ 1 ฉ $2 \times 3 \bullet 4+5 \Delta 6\llcorner 7 ه 8 \Delta 9 \star 10 \square 11 \diamond 12 * 13$

Рис. 4. Соотношение Fo в Ol-mg в породах Кекукнайского массива.

Fo - содержание молекулы форстерита в оливине (\%), $\mathrm{mg}(\%)$ - магнезиальность вмещающей породы: $(\mathrm{mg}=\mathrm{Mg} / \mathrm{Mg}+$ $\left.+\mathrm{Fe}^{*}\right)$, где $\mathrm{Fe}^{*}=\left(\mathrm{Fe}_{2} \mathrm{O}_{3} \times 0.8998+\mathrm{FeO}\right) / 71.85 \times 1000$

$\underline{\mathrm{Sp}}_{44-47}-$ Fо в оливине с включением шпинели, содержащей 44-47 $\mathrm{Al}_{2} \mathrm{O}_{3}$ (вес. \%), $\underline{\mathrm{mt}}-$ Fо в оливине с включением магнетита.

1 - докальдерная стадия (трахибазальты постройки щитообразного вулкана); $2-5$ - ранняя стадия ареального вулканизма: 2-4 - трахибазальтовая ассоциация, породы: 2 - некка (обр. к53), 3 - шлакового конуса (обр. к50), 4 - потоков (обр. 49058, к57), 5 - амфиболовые андезибазальты шлаковых конусов; 6-10 - средняя стадия ареального вулканизма: 6-8 гавайиты: безамфиболовые (6), амфиболовые (7), в зоне распада амфибола (8), 9 - андезибазальты, 10 - муджиериты; 11-13 - поздняя стадия ареального вулканизма: 11 - трахибазальты, 12 - муджиериты, 13 - андезибазальты (обр. к51).

Номера образцов соответствуют приведенным на рис. 2. Сплошной линией показана граница начальных составов оливинов для большинства разностей пород.

ганца в оливине, которое даже превышает таковое для щелочных разностей пород Белоголовского вулкана.

Клинопироксен представлен преимущественно авгитом с $\mathrm{mg}=82-68$ в трахибазальтах (рис. 6 , обр. $136,141,144,161)$ и $\mathrm{mg}=76-74$ в трахиандезите (см. рис. 6, обр. к46), но этот показатель не коррелируется с магнезиальностью вмещающей породы. Аномальными являются образцы 141 и 144, пироксены в которых по магнезиальности являются такими же, как образовавшиеся ранее их оливины первых генераций. Для клинопирок- сенов (и особенно для ортопироксенов) отмечается “пик” содержания MnO, независимо от железистости минералов (см. рис. 5б). Тренд прямой корреляционной зависимости $\mathrm{TiO}_{2}-\mathrm{Al}$ и $\mathrm{TiO}_{2}-\mathrm{F} / \mathrm{FM}$ (рис. 7а и 7б) усложняется появлением “облака” фигуративных точек в некоторых трахибазальтах в области высоких значений $\mathrm{TiO}_{2}$ (обр. 141), т.е. в тех же самых разностях пород с аномальной магнезиальностью оливинов и пироксенов. Подобные отклонения от общего тренда прямой корреляционной зависимости не является следствием

Pис. 5. Соотношение MnO-Fo в оливинах и MnO-mg в клинопироксенах Кекукнайского массива.

а-б - докальдерная стадия: 1 - трахибазальты постройки щитообразного вулкана, 2 - трахиандезиты экструзий; в-Г - ранняя стадия ареального вулканизма: $3-6$ - трахибазальтовая ассоциация, породы: 3 - некка (обр. к53), $4-$ шлакового конуса (обр. к50), 5 - потоков (обр. 49058, к57), 6 - амфиболовых андезибазальтов шлаковых конусов; д-е - средняя стадия ареального вулканизма: 7-9 - гавайиты: безамфиболовые (7), амфиболовые (8), в зоне распада амфибола (9), 10 - муджиериты, 11 - андезибазальты; ж-з - поздняя стадия ареального вулканизма: 12 - трахибазальты, 13 - муджиериты, 14 - андезибазальты (обр. к51).

Залитое - поле составов оливинов трахибазальтовой ассоциации ранней стадии ареального вулканизма, не залитое для пород различных регионов из работы [Волынец и др., 1975]. Сплошной линией отделены предельные содержания $\mathrm{MnO}$ в оливинах щелочных пород Белоголовского вулкана (объяснение в тексте). 

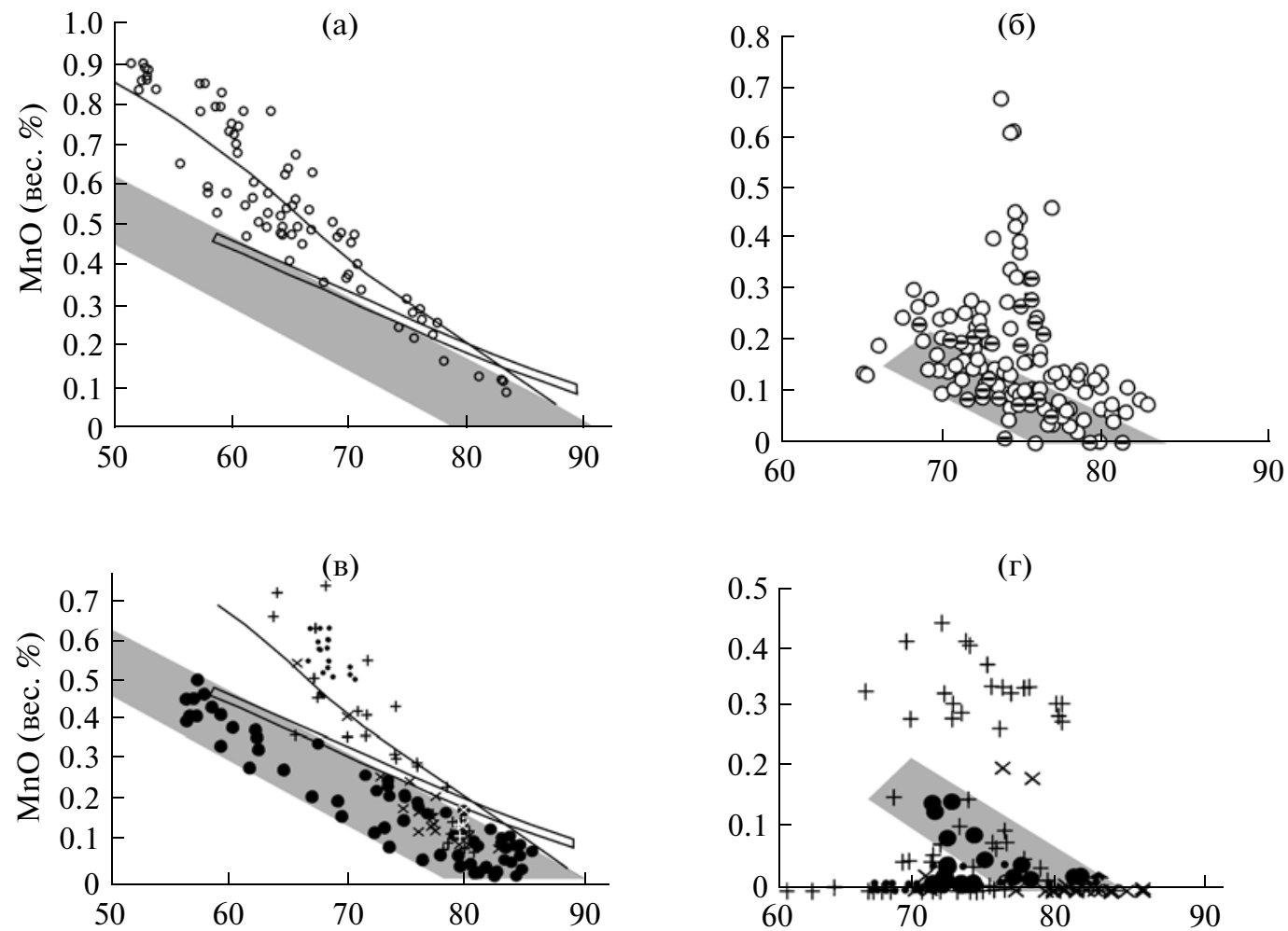

(г)
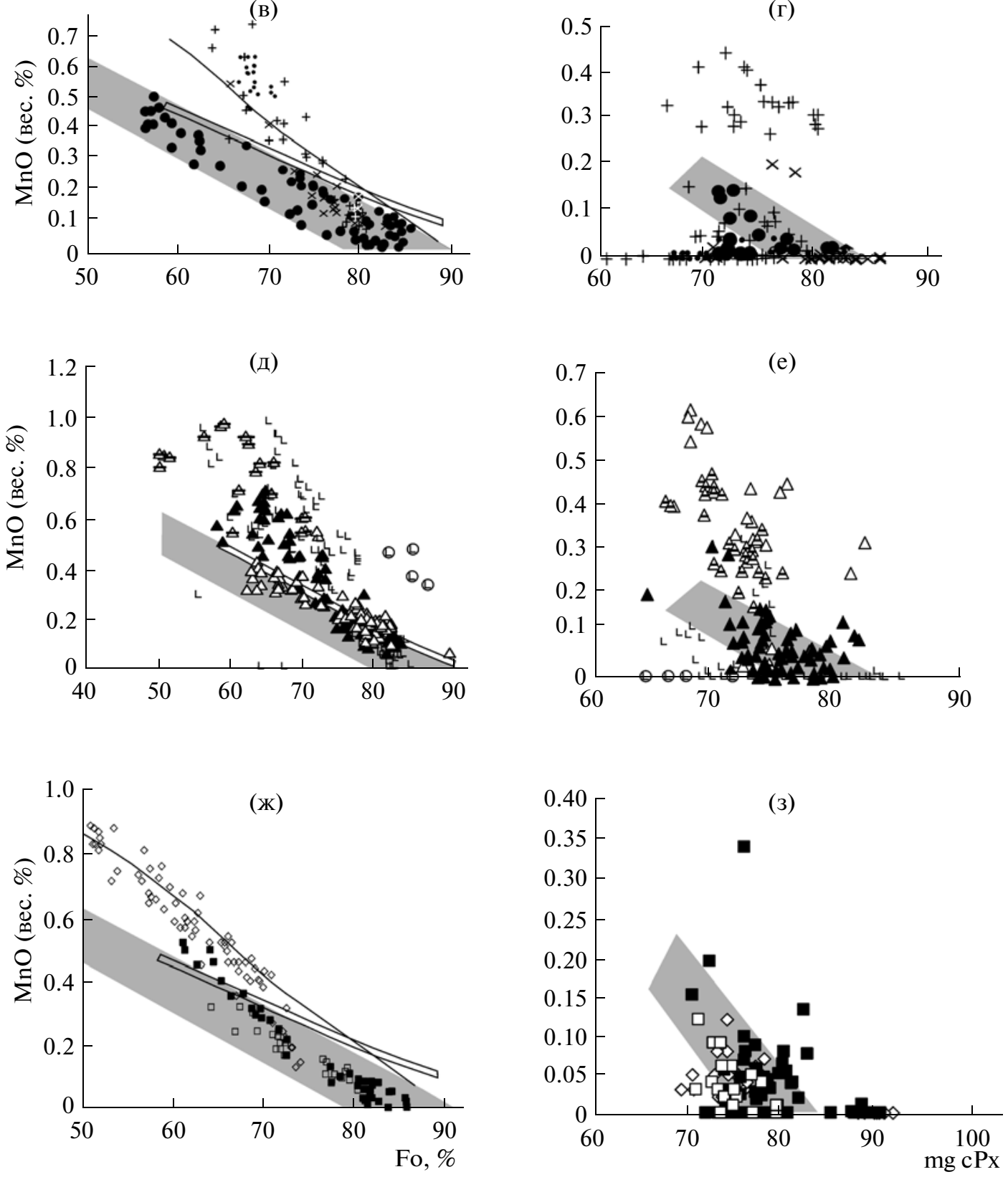

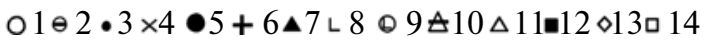




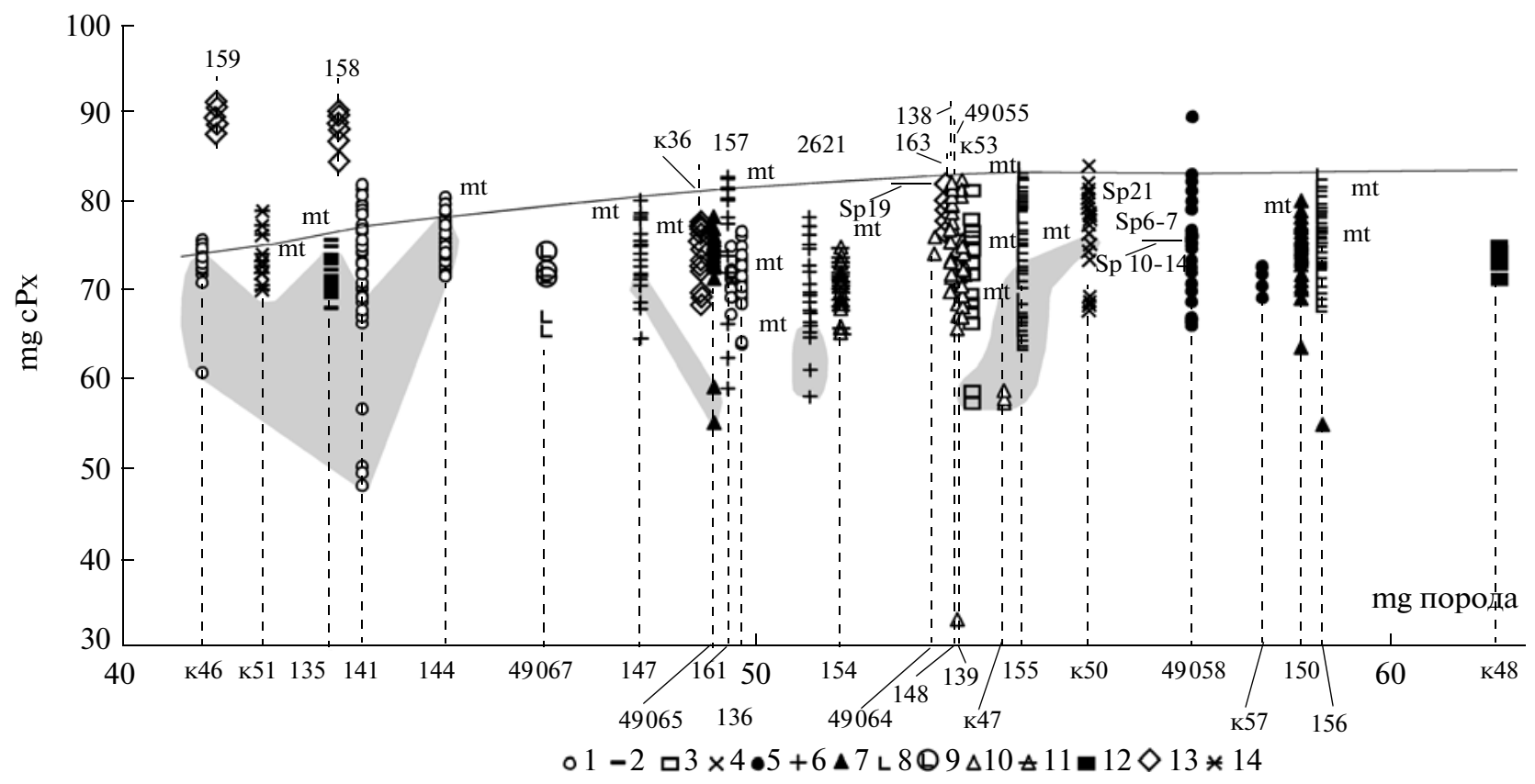

Рис. 6. Соотношение магнезиальность пироксена (mg Px) - магнезиальность породы (mg породы) вулканитов Кекукнайского массива.

$\mathrm{mg} \mathrm{Px}-\mathrm{Mg} / \mathrm{Fe}$ (сумм.) в \% об, mg породы - то же, что и на рис. 4.

1-2 - докальдерная стадия и экструзии: 1 - трахибазальты постройки щитообразного вулкана), 2 - трахиандезиты экструзий; 3-6 - ранняя стадия ареального вулканизма: 3-5 - трахибазальтовая ассоциация, породы: 3 - некка (обр. к53), 4 - шлакового конуса (обр. к50), 5 - потоков (обр. 49058, к57), 6 - амфиболовые андезибазальты шлаковых конусов; 7-10 - средняя стадия ареального вулканизма: 7-9 - гавайиты: безамфиболовые (7), амфиболовые (8), в зоне распада амфибола (9), 10 - андезибазальты, 11 - муджиериты; 12-14 - поздняя стадия ареального вулканизма: 12 трахибазальты, 13 - муджиериты, 14 - андезибазальты (обр. к51).

$\underline{\mathrm{Sp} 10.45}$ и $\underline{\mathrm{mt}}-$ то же, что и на рис. 3 относительно магнезиальности пироксена. Сплошной линией показана граница магнезиальности (Fo \%) начальных составов оливинов для тех же образцов. Серым фоном выделено поле составов ортопироксенов. Номера образцов соответствуют приведенным на рис. 2.

разного содержания $\mathrm{TiO}_{2}$ в самой породе: $\mathrm{TiO}_{2}=$ $=0.94$ (обр. 141) и $\mathrm{TiO}_{2}=1.08$ (обр. 161).

Ортопироксен по железистости $\left(\mathrm{f}_{38.6-20}\right)$ отвечает гиперстену. Его состав также не коррелируется с магнезиальностью пород (см. рис. 6).

Состав плагиоклаза колеблется от $\mathrm{An}_{83}$ до $\mathrm{An}_{8}$ в трахиандезитах и от $\mathrm{An}_{88}$ до $\mathrm{An}_{8}$ в трахибазальтах (см. табл. 1). При этом верхний предел содержания An минерала достигает уровня составов в щелочных породах вулкана Белоголовского (рис. 8a).

Трахиандезиты и трахидациты экструзий этапа кальдерообразования. Различаются следующие петрографические разности: более основные, оливинсодержащие - двупироксеновые и пироксен-роговообманковые трахиандезиты; роговообманковые кислые трахиандезиты и биотит-роговообманковый трахидацит. Всем этим разностям свойственна серийно-порфировая структура и трахитоидная микроструктура основной массы. Доля вкрапленников различна и составляет от 15-25 до 40 об. \%. Вкрапленники, размером до 3 мм, и субфенокристаллы представлены плагиоклазами, пироксенами, амфиболом (паргасит), ти- таномагнетитом при переменном соотношении минеральных фаз, но всегда преобладает плагиоклаз. В основных андезитах присутствует оливин, в трахидацитах - биотит. Для основных разностей характерны габброидные и, реже, мелкозернистые пироксенитовые микровключения. Микролиты основной массы представлены плагиоклазом (андезин - олигоклаз), ортопироксеном и магнетитом, встречается апатит. Клинопироксен присутствует только в основных андезитах. Интерстиции сложены кварц (?) - полевошпатовым микрокристаллическим агрегатом. Состав плагиоклазов трахиандезитов колеблется от $\mathrm{An}_{64}$ до

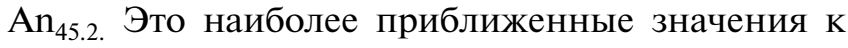
расчетным составам (см. табл. 1) и к средним составам для известково-щелочных серий (см. рис. 8, обр. 135). Характерна зональность (прямая, повторная, пятнистая) с резорбированными ядрами кристаллов. Роговая обманка всегда в той или иной степени опацитизирована, ее порфировые выделения часто корродированы основной массой. Железистость клинопироксенов $\left(\mathrm{f}_{24-31.3}\right)$ и ортопироксенов $\left(\mathrm{f}_{26.3-31.3}\right)$ практически одинакова 

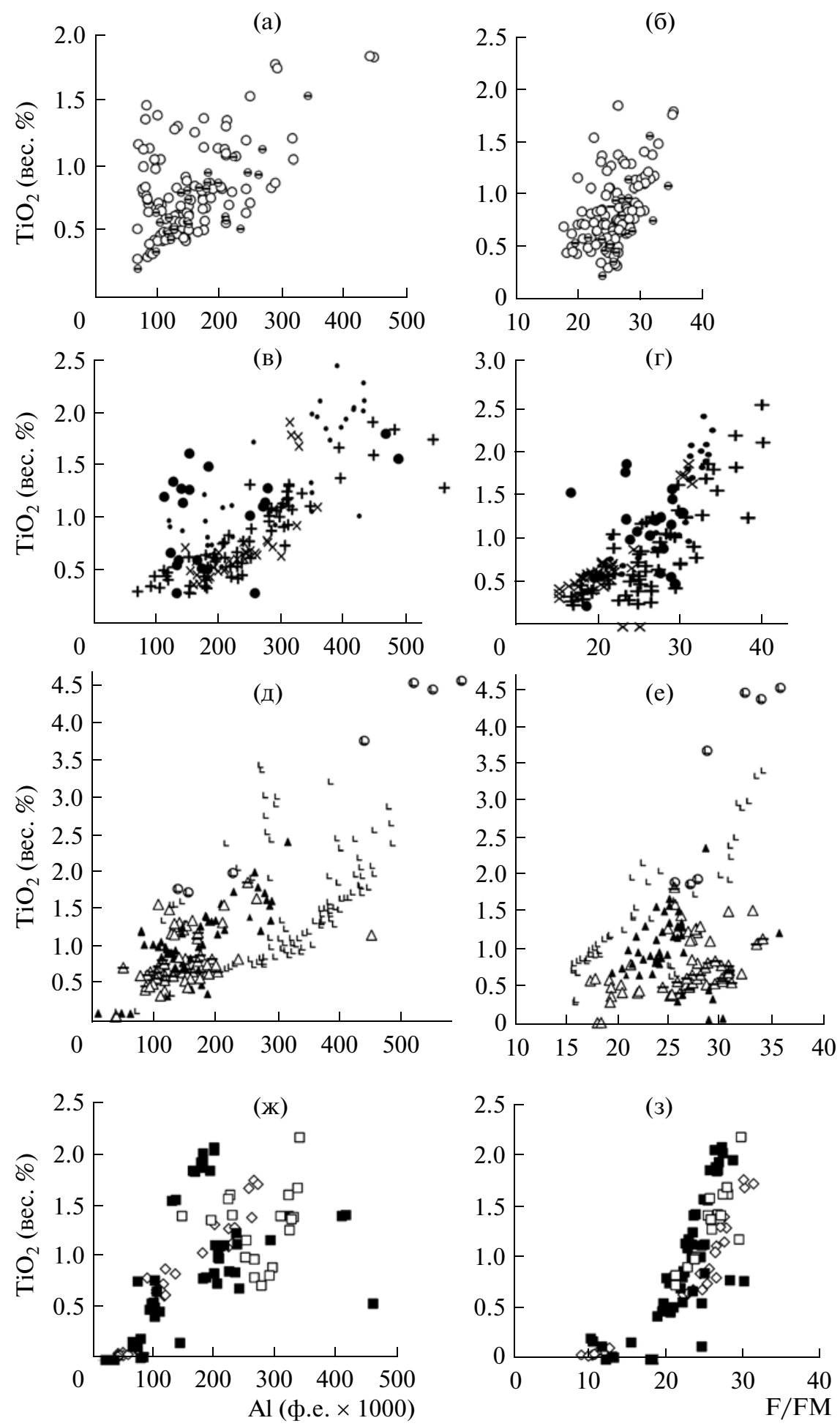

$\circ 1 \oplus 2 \cdot 3 \times 4 \bullet 5+6 \Delta 7\llcorner 8 \bullet 9 \Delta 10 \Delta 11 \bullet 12 \diamond 13 \square 14$

Рис. 7. Соотношение $\mathrm{TiO}_{2}-\mathrm{Al}$ и $\mathrm{TiO}_{2}-\mathrm{F} / \mathrm{FM}$ в клинопироксенах из пород Кекукнайского массива. а-3 и 1-14- то же, что и на рис. 5.

и не отличается от подобных характеристик трахиандезитов постройки вулкана (см. табл. 1).

Ареальные трахибазальты наиболее распространены на ранней стадии посткальдерного вул- канизма (см. рис. 1а, ассоциация III). Обнаружены в пирокластике шлаковых конусов (обр. 49057 и к50), лавовых потоках (обр. к57 и 49058) и некках (обр. к53). Структуры основной массы разли- 


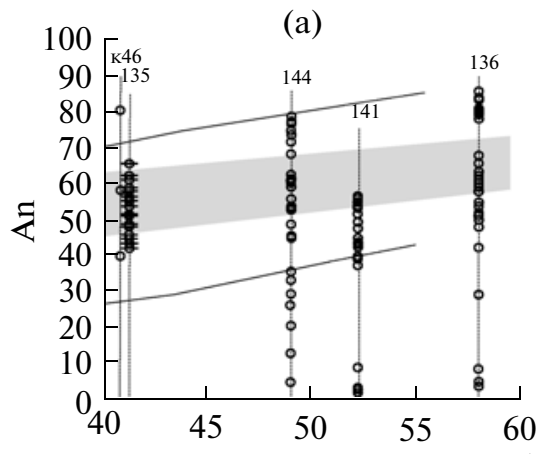

(б) $\mathrm{Pl}$, норм (\%)

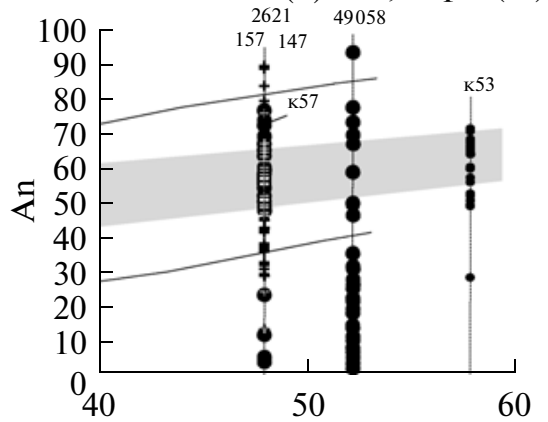

(в) $\mathrm{Pl}$, норм (\%)

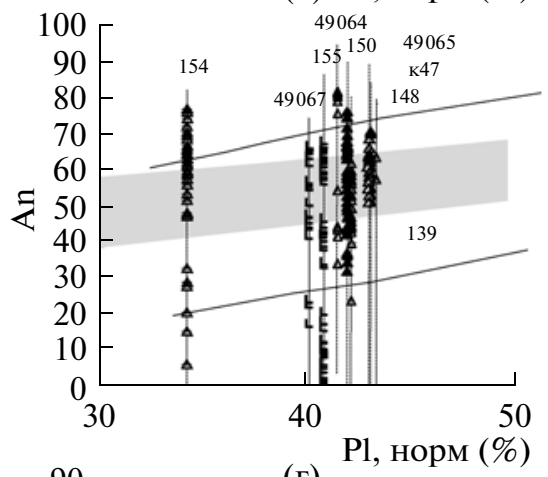

(г)

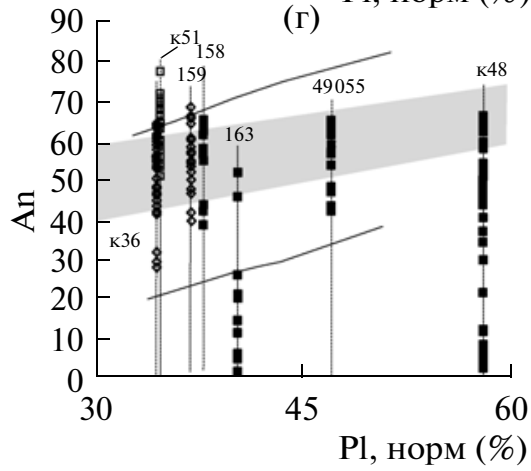

$01 \bullet 2 \cdot 3 \times 4 \bullet 5+6 \Delta 7\llcorner 8 \star 9 \Delta 10 \bullet 11 \diamond 12 \square 13$

чаются в соответствии с фациальной принадлежностью породы: от гиалопилитовой с криптокристаллическим стеклом в шлаках, пилотакситовой с раскристаллизованной микрозернистой полевошпатовой матрицей в интерстициях между флюидально расположенными микролитами плагиоклаза и кали-натрового полевого шпата - в лавовых потоках, до микродолеритовой - в некке. Обычный набор вкрапленников-субфенокристал-
Рис. 8. Соотношение модального (An) и нормативного (№ Pl норм.) составов плагиоклазов из пород $\mathrm{Ke}-$ кукнайского массива.

Стадии проявления вулканизма: а - докальдерная и экструзии, б - ранняя, в - средняя, г - поздняя ареального вулканизма

1-8 - то же, что и на рис. 5; 9 - муджиериты, 10 - андезибазальты; 11-13 - поздняя стадия ареального вулканизма: 11 - трахибазальты, 12 - муджиериты, 13 - андезибазальты (обр. к51).

Серым фоном выделены поля составов плагиоклазов вкрапленников из четвертичных вулканитов известково-щелочной серии Камчатки, по данным [Волынец, Колосков, 1976]. Сплошными линиями ограничены составы плагиоклазов щелочных базальтоидов Белоголовского вулкана. Объяснение в тексте. Составы плагиоклазов даны в \% содержания анортитовой (An) молекулы.

лов: оливин, клинопироксен; плагиоклаз резко в подчиненном количестве, во вкрапленниках часто отсутствует. Ортопироксен присутствует только в трахибазальтах некка. В образцах из конусов и потоков оливин (также как и клинопироксен) содержит включения хром-глиноземистой шпинели и титаномагнетита, а в породах некка - только включения титаномагнетита (см. рис. 2). В базисе основной массы присутствует калиевый полевой шпат. Важно подчеркнуть, что в ареальных трахибазальтах калиевые полевые шпаты преимущественно присутствуют не в гранофировых агрегатах интерстиционного пространства, как в гавайитах, а слагают существенную долю полевошпатовых микролитов.В целом состав оливинов из трахибазальтов изменяется от $\mathrm{Fo}_{86}$ до $\mathrm{Fo}_{56}$ (см. табл. 1) и не коррелируется с магнезиальностью вмещающих пород. В потоках (обр. 49058, к57) они наиболее магнезиальны с широким диапазоном вариаций составов $\left(\mathrm{Fo}_{86-68}\right)$. Здесь наблюдается хорошо выраженная отрицательная корреляция Fo- $\mathrm{MnO}$ (см. рис. 5в) с невысоким уровнем накопления $\mathrm{MnO}$, что соответствует относительно низкой суммарной щелочности этого типа пород (см. рис. 2г). Уровень изменения соответствующих характеристик выделен обособленным полем для сравнения с другими составами. Наиболее раскристаллизованные и флюидонасыщенные породы некка (обр. к53) имеют довольно узкий диапазон изменения составов оливина $\left(\mathrm{Fo}_{71-67}\right)$, но отличаются аномально высокими содержаниями $\mathrm{MnO}$ (см. рис. 5в). Трахибазальты конуса (обр. к50) имеют меньший диапазон изменения составов оливина $\left(\mathrm{Fo}_{81-66}\right)$, но характеризуются также повышенной марганцовистостью.

По магнезиальности клинопироксены (отвечающие по составу салит-авгиту) из трахибазальтов конуса, потока и некка близки $\left(\mathrm{mg}_{84-66}\right)$, а первые их генерации соответствуют магнезиальности оливинов (см. рис. 6, обр. к50, 49058, к53) 

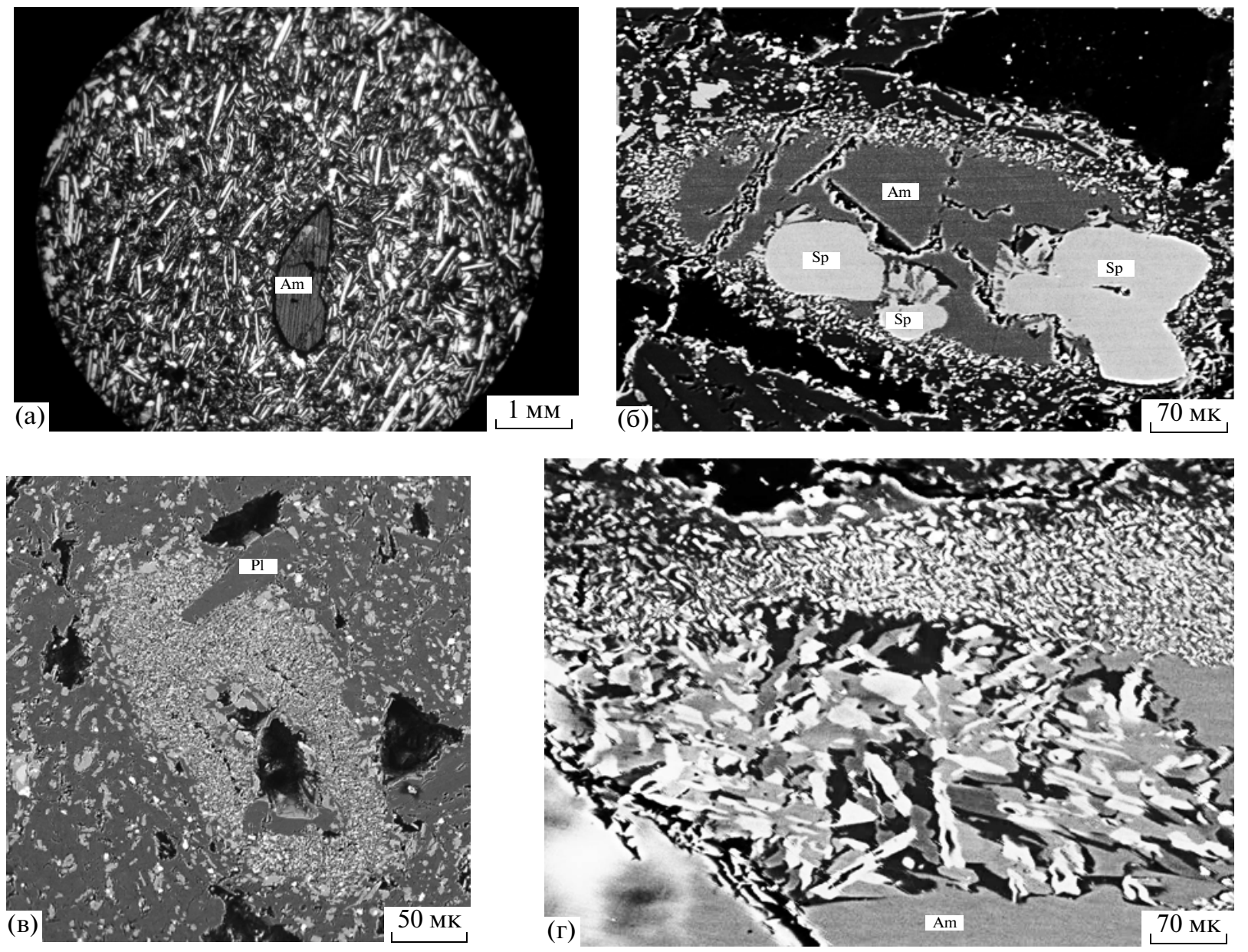

Рис. 9. Разномасштабные фотографии амфиболов и его реликтовых образований в породах Кекукнайского массива. а - вкрапленник амфибола с реакционной каймой (микрофото в скрешенных николях); б - редкий случай включений высокоглиноземистой шпинели в амфиболе; в - разложенный “апоамфибол"; г - фрагмент реакционной каемки и участок распада амфибола (плагиоклаз, клинопироксен, оливин, рёнит, магнетит, стекло, вторичный амфибол). а, б, г - в гавайите (обр. 49067), в - в андезибазальте (обр. 147). б, в, г - изображения в обратнорассеянных электронах.

из тех же образцов. Можно также отметить, что клинопироксены из трахибазальтов конуса для большинства составов более глиноземистые (см. рис. 7в, обр. к50), а из трахибазальтов некка отличаются повышенным содержанием титана (см. рис. 7в, обр. к53). Средний уровень содержания анортита в ранних генерациях плагиоклаза слегка “не дотягивает” до границы щелочных пород Белоголовского вулкана, особенно это касается некка (см. рис. 8 б), что соответствует низкой суммарной щелочности анализированных трахибазальтов (см. рис. 2г).

Андезибазальты шлаковых конусов. Здесь мы рассмотрим промежуточную группу андезибазальтов (группа II на диаграмме $\mathrm{Nb}-\mathrm{K}$ см. рис. 2a), отнесенных к ранней стадии ареального вулканизма, хотя значительная часть такого типа пород присутствует в составе ассоциаций средней и поздней стадий.
Это редко-мелкопорфировые породы, доля вкрапленников не превышает 6 об. \%, а их размеры обычно менее 1 мм. Микроструктура основной массы гиалопилитовая, гиалопилотакситовая. Встречаются гломеропорфировые сростки размером до 3 мм, характерно наличие мелкозернистых обособлений оливиновых пироксенитов, иногда в ней можно видеть и плагиоклаз. Во вкрапленниках и субфенокристаллах встречаются плагиоклаз, клинопироксен, оливин, ортопироксен и обязательно присутствует либо реликтовый паргасит, либо продукты его распада. Этот распавшийся амфибол (апоамфибол) (рис. 9в), представляет собой полностью разложенный кристалл амфибола до образования тонкозернистого полиминерального агрегата: амфибол + + плагиоклаз + Ті-магнетит + клино- и ортопироксен + стекло. Наличие такого агрегата свидетельствует о возрастающей неравновесности амфибола с расплавом, а его диссоциация, по-видимому, свя- 
КОЛОСКОВ и др.

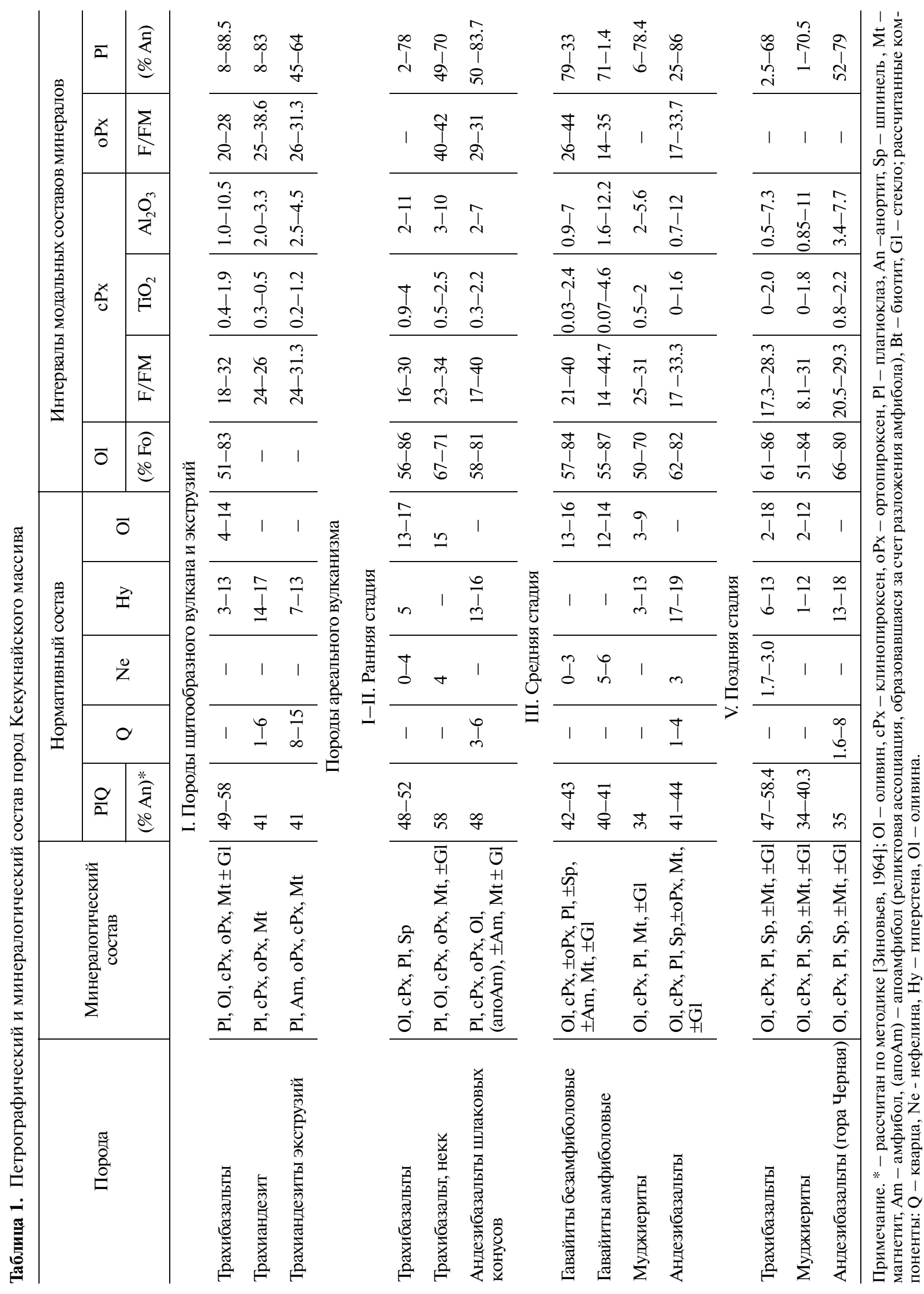

ВУЛКАНОЛОГИЯ И СЕЙСМОЛОГИЯ № 22013 
зана с возрастанием окислительного потенциала кислорода в результате изменившихся термодинамических условий кристаллизации. Основная масса содержит микролиты плагиоклаза, клинопироксена, магнетита, обычно присутствует оливин, редко щелочной полевой шпат. Стекло обычно криптокристаллическое, переполненное кристаллитами, реже свежее буроватое.

Предельная магнезиальность оливинов андезибазальтов: $\mathrm{Fo}_{81-78}$ выше, чем те же характеристики в наиболее магнезиальных базальтах постройки: $\mathrm{Fo}_{78-75}$ при практически одинаковой магнезиальности вмещающих пород (см. рис. 4, обр. 157 и 161), но такая же, как в “аномальном" по составу субликвидусном оливине трахибазальта щитообразного вулкана (см. рис. 4, обр. 144). То же можно утверждать и в отношении клинопироксенов, при том, что диапазон изменения составов этого минерала для андезибазальта значительно шире (см. табл. 1, рис. 6). И оливины, и клинопироксены этой группы пород характеризуются высокими содержаниями $\mathrm{MnO}$ (см. рис. 5В и 5Г). Клинопироксены андезибазальтов и трахибазальтов сходны по содержанию $\mathrm{TiO}_{2}$ и $\mathrm{Al}$, но первые отличаются в целом большей железистостью (см. рис. 7г). В оливине (обр. 157, $\mathrm{Fo}_{80}$ ) обнаружено включение высокоалюминиевого $\left(\mathrm{Al}_{2} \mathrm{O}_{3}=\right.$ $=12.0)$ и высокотитанистого $\left(\mathrm{TiO}_{2}=1.8\right)$ клинопироксена и расплавное включение сложного состава. Оно состоит из андезитового стекла + высокоалюминиевый $\left(\mathrm{Al}_{2} \mathrm{O}_{3}=16.9-19.7\right)$ и высокотитанистый $\left(\mathrm{TiO}_{2}=1.9-2.2\right)$ клинопироксен.

Основность плагиоклазов андезибазальтов колеблется: $\mathrm{An}_{89-32}$ (см. табл. 1). Это наиболее аномальные по сравнению с расчетными составы (см. рис. 8, обр. 147, 157, 2621). Наряду со свежим битовнитом иногда отмечается наличие обратно зональных вкрапленников плагиоклаза с кислыми губчатыми ядрами и инверсионными зонами, переполненными стекловатыми микровключениями.

Гавайиты - преобладающий тип пород средней стадии ареального вулканизма (см. рис. 2a, IV), хотя единичные составы этого типа встречаются и на поздней стадии.

Обычно - это субафировые или редко - мелкопорфировые породы. Относительно крупные вкрапленники, немногочисленны. Доля порфировых выделений (до 1.5-2 мм в поперечнике) не превышает 5-6 об. \%. Структуры основной массы разнообразны и определяются фациальной принадлежностью породы.

Наблюдаются микродолеритовая, интерсертальная, пилотакситовая, флюидальная и гиалопилитовая микроструктуры. Первые характерны для пород из даек и потоков, последняя свойственна шлакам и бомбам.
В количественном отношении среди вкрапленников и субфенокристаллов доминирует оливин, в подчиненном значении - клинопироксен и плагиоклаз. Встречаются также вкрапленники опацитизированного (иногда диссоциированного) амфибола - паргасита (см. рис. 9а, 9б, 9г). Зональные вкрапленники амфибола с опацитовой каймой обнаружены в закаленной микропористой пирокластике полуразрушенных конусов (обр. 49066, 49067). Теневые формы распада роговой обманки встречены в гавайитах некка и дайки (обр. 156, 155). Для пород даек и некков характерны и другие отличительные особенности. Им присуще возрастание железистости в краевых зонах относительно крупных вкрапленников оливина и клинопироксена, присутствие оливинов, резорбированных основной массой, повышенная кристалличность за счет большого количества субфенокристаллов, присутствие разнообразных гломеропорфировых сростков и неоднородностей (микровключений оливиновых долеритов, оливиновых пироксенитов). Отмечаются также ксенокристаллы кислого плагиоклаза с инверсионными зонами, переполненными апостекловатыми микровключениями (обр. 156), оливина с каймой гиперстена, кварца в пироксеновой оторочке.

Для гавайитов характерна ранняя кристаллизация глиноземистой шпинели (см. рис. 3, 9б). Наиболее глиноземистые шпинели были обнаружены в магнезиальных оливинах $\left(\mathrm{Fo}_{83-85}\right)$ некка и дайки (см. рис. 4, обр. 155 и 150). В составе основной массы присутствует магнетит.

При близкой магнезиальности оливины безамфиболовых гавайитов и ареальных трахибазальтов укладываются в поле коррелятивной зависимости Fo-MnO. Однако для оливинов амфиболовых гавайитов наблюдается существенное отклонение в сторону повышенной марганцовистости даже в магнезиальных составах с перекрытием границы для того же минерала из щелочных пород Белоголовского вулкана (см. рис. 5в и 5д). Оливины, образовавшиеся при распаде вкрапленников амфибола (в парагенезисе с магнетитом), характеризуются резко повышенной магнезиальностью (до $\mathrm{Fo}_{88-84}$ ) и высокими содержаниями $\mathrm{MnO}$ (см. рис. 5д) и $\mathrm{CaO}$ (до 0.8-1.0 вес. \%). Этим они существенно отличаются от оливинов трахибазальтов, где аномальная марганцовистость наблюдается только в составе некка.

Клинопироксены гавайитов и ареальных трахибазальтов по магнезиальности и содержанию $\mathrm{MnO}$ практически не различаются (см. рис. 5г и 5е). При этом клинопироксены амфиболовых гавайитов, в отличие от безамфиболовых разностей, характеризуются заметным обогащением $\mathrm{Al}$ и $\mathrm{TiO}_{2}$ (см. рис. 7д и 7е). Повышенная титанистость иногда коррелируется с высокими содер- 

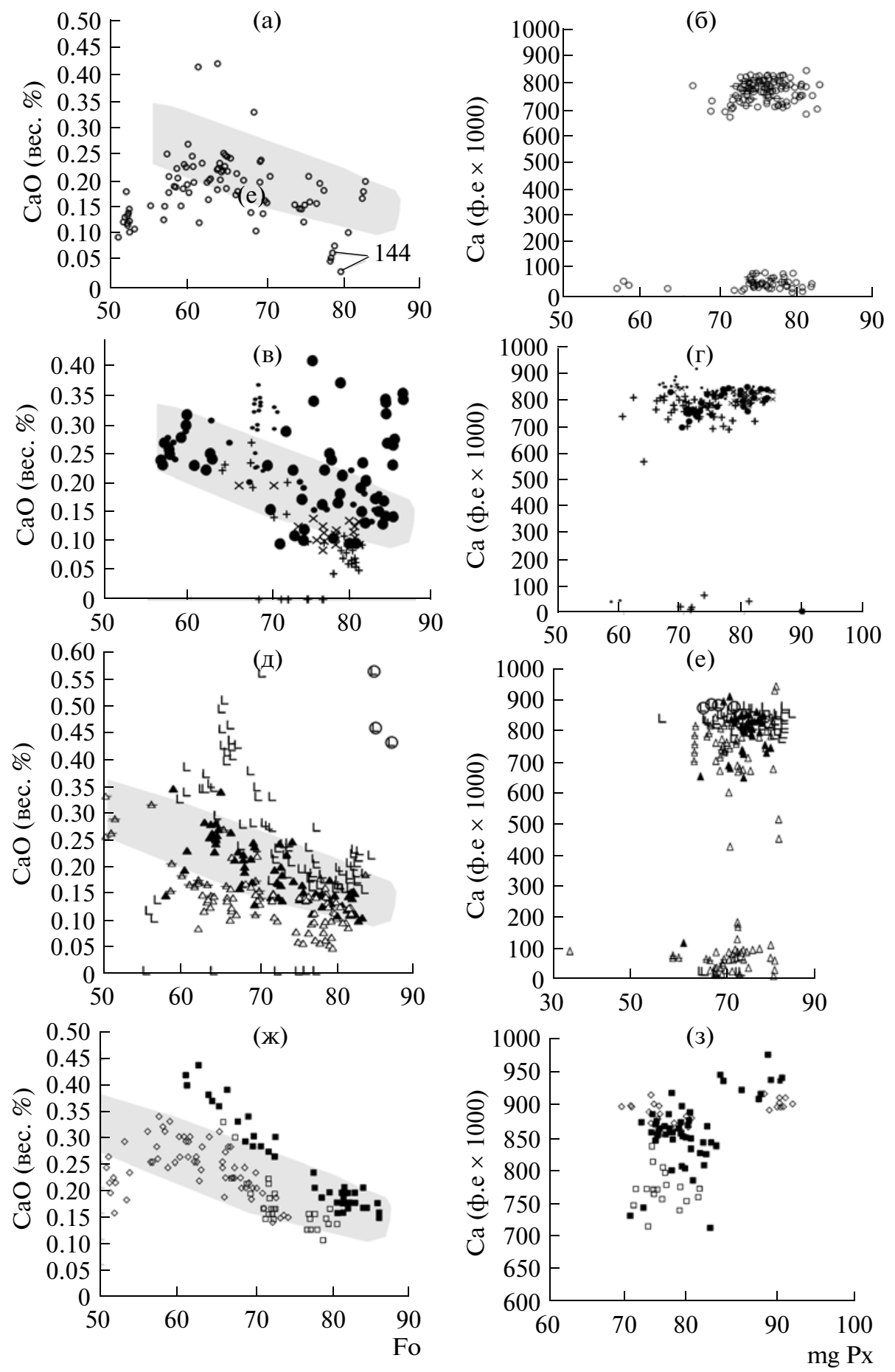

$01 \oplus 2 \cdot 3 \times 4 \bullet 5+6 \Delta 7\llcorner 8 \oplus 9 A 10 \Delta 11 \cdot 12 \diamond 13 \square 14$

Рис. 10. Соотношение CaO-Fo в оливинах (а, в, д, ж) и Сa-mg в клинопироксенах (б, г, е, з) из пород Кекукнайского массива.

а-3 и 1-14- то же, что и на рис. 5 .

Выделено поле коррелятивных составов оливинов трахибазальтовой ассоциации.

жаниями этого элемента во вмещающей породе. Но в некоторых умеренно титанистых гавайитах (с вкрапленниками Ті-амфибола) также могут присутствовать клинопироксены с особо высокими содержаниями $\mathrm{TiO}_{2}$. Плагиоклазы гавайитов отличаются существенно пониженными норма- 
тивными составами при том, что их субликвидусные генерации значительно обогащены анортитовой молекулой (см. рис. 8в). При этом среди плагиоклазов некка по составу выделяются по крайней мере три генерации (см. рис. 8в, обр. 155).

Муджиериты в равной мере распространены как на средней, так и на поздней стадиях ареального вулканизма (см. рис. 2a, IV-V). Поэтому приводится их совместная характеристика. От гавайитов они, прежде всего, отличаются тем, что в нормативном составе отсутствует нефелин, появляется гиперстен, хотя модальный ортопироксен не обнаружен. Породы обычно субафировые, встречаются мелко-редкопорфировые разности. Структуры основной массы серийно-порфировые, микродолеритовые, пилотакситовые. Среди субфенокристаллов доминирует плагиоклаз, но встречаются оливин и клинопироксен. В основной массе присутствуют микролиты оливина, клинопироксена, плагиоклаза, титаномагнетита, щелочного полевого шпата, в базисе присутствует калиевый полевой шпат. Кристаллизация минералов муджиеритов происходила в парагенезисе с магнетитом, хотя в одном из образцов поздней стадии (обр. к36/1) в оливине обнаружены включения хром-глиноземистой шпинели. Несмотря на то, что диапазон изменения составов (Fo) оливинов муджиеритов, гавайитов и трахибазальтов во многом совпадает, первые имеют большее сходство с оливинами трахибазальтов докальдерной постройки (см. рис. 4, 5а, 5д, 5ж), (см. рис. 10a, 10д, 10ж): а именно, максимум железистых составов, максимальное обогащение $\mathrm{MnO}$, уменьшение содержаний СаО в области железистых генераций. То же можно отметить и в отношении клинопироксенов - в целом они более железистые, с повышенным содержанием $\mathrm{MnO}$ и пониженным $\mathrm{TiO}_{2}$, отличаясь от пироксенов трахибазальтов и гавайитов, но приближаясь к составам минералов из трахибазальтов постройки (см. рис. 4, 5б, 5е, 5з; 7б, 7е, 7з). При этом некоторые муджиериты поздней стадии характеризуются наличием аномально магнезиальных генераций пироксена (см. рис. 6 , обр. 158, 159). Но такие магнезиальные пироксены (также, как и оливины) наблюдаются и в андезибазальтах этой стадии (гора Черная). Причины таких отклонений будут рассмотрены далее при обсуждении результатов.

Нормативные составы плагиоклазов муджиеритов отвечают андезинам, но в модальном составе они резко выделяются повышенными содержаниями анортита. Интересно, что подобные отклонения наблюдаются также в образцах муджиеритов поздней стадии и андезибазальтах горы Черная (см. рис. 8в, 8г).

Андезибазальты гавайит-муджсеритовой ассоциации средней стадии ареального вулканизма. Структуры пород субафировые, редко слабопор- фировые. Относительно крупные вкрапленники, размером до 1.5 мм в поперечнике, немногочисленны (не более 3-5 об. \%). Представлены они оливином, клинопироксеном, реже ортопироксеном; плагиоклаз более обычен в мелких субфенокристаллах, где доминирует в количественном отношении. Пироксены иногда обрастают зерна оливина и образуют сростки между собой. В некках (обр. 139) наблюдается высокая доля (до 40 об. \%) субфенокристов с размерами менее 0.5 мм. Основная масса андезибазальтов некка (обр. 139) обычно характеризуется гиалопилитовой микроструктурой и сложена микролитами плагиоклаза, ортопироксена, клинопироксена, оливина и криптокристаллическим стеклом, насыщенным рудной пылью. В потоках (обр. 148, 138) наблюдается пилотакситовая и толеитовая (микродолеритовая с небольшим количеством стекла) микроструктуры при аналогичном наборе микролитов с микрозернистым полевошпатовым интерстиционным заполнением.

В магнезиальных ортопироксене $\left(\mathrm{mg}_{82.4}\right)$ некка (обр. 139) и оливинах $\left(\mathrm{Fo}_{69-66}\right.$ и $\left.\mathrm{Fo}_{81-79}\right)$ потоков (обр. 148, к47) была обнаружена хром-алюминиевая шпинель (см. рис. $3,4,6)$. В случае более железистых составов кристаллизация минералов идет в парагенезисе с титаномагнетитом. В центре кристаллов клинопироксена из протолочной пробы пород лавового потока (обр. 138) и шлакового конуса (49064) отмечена локальная область, по составу отвечающая обыкновенной роговой обманке.

Сравнительно с гавайитами и ареальными трахибазальтами состав оливинов начальных фаз менее магнезиальный $\left(\mathrm{Fo}_{82}\right.$ против $\left.\mathrm{Fo}_{85-86}\right)$. Интересно отметить, что оливины некка (см. рис. 4, обр. 139) имеют ссуженный интервал составов (Fo $\mathrm{Fo}_{72-62}$ против $\mathrm{Fo}_{82-62}$ в целом для андезибазальтов) и по этому параметру уступают ортопироксену ( $\mathrm{mg}_{84-82)}$ (см. рис. 6, обр. 139)

По соотношению Fo-MnO (см. рис. 5д) основная часть оливинов андезибазальтов продолжает четко выраженный коррелятивный тренд безамфиболовых гавайитов - андезибазальтов. При этом точки составов амфиболовых гавайитов и муджиеритов образуют самостоятельное поле с высокими содержаниями $\mathrm{MnO}$ и выходом за рамки состава оливинов щелочных пород Белоголовского вулкана. Клинопироксены и андезибазальтов, и муджиеритов обогащены $\mathrm{MnO}$ (см. рис. 5e) в значительно большей степени, чем тот же минерал в одноименных породах ранних стадий (см. рис. 5б и 5г). По соотношению $\mathrm{TiO}_{2}-\mathrm{F} / \mathrm{FM}$ (см. рис. 7е) клинопироксены андезибазальтов располагаются в одном поле с точками составов того же минерала безамфиболовых относительно менее титанистых гавайитов. Для тех и других также характерна низкая глиноземистость этого 
минерала (см. рис. 7д). Ортопироксены по составу отвечают гиперстену с содержанием ферросилитового минала $18-34 \%$.

Точки модальных составов плагиоклазов в основном укладываются в поле подобного минерала из щелочных пород Белоголовского вулкана, за исключением составов из амфибол-содержащего андезибазальта (обр. 49064) со значениями An $86-84$ (см. рис. 8).

Таким образом, составы минералов различных типов пород и различных возрастных групп существенно различаются. При этом некки и дайки, как правило, “выбиваются” из общей закономерности. Вызвано это тем, что некки являются проводникам флюидных потоков, а дайки отличаются продвинутостью процессов клисталлизации, о чем уже говорилось в 1-ой части статьи. Поэтому эти проявления рассматриваются иногда отдельно в группе сходных по составу пород.

Минералогические различия связаны, с одной стороны, с особенностями состава самих пород, прежде всего их щелочности (положение верхней границы полей на диаграммах составов оливинов и плагиоклазов), в меньшей степени - магнезиальности и титанистости (например, высокотитанистые гавайиты содержат клинопироксены с повышенным содержанием $\mathrm{TiO}_{2}$ ).

С другой стороны, можно констатировать, что повышенные концентрации $\mathrm{MnO}$ при пониженных значениях $\mathrm{CaO}$ в оливинах можно рассматривать как показатель высокой фугитивности кислорода; повышенные же значения и $\mathrm{MnO}$, и $\mathrm{CaO}$ в оливинах, наряду с повышенной магнезиальностью темноцветных минералов и высокими содержаниями An-молекулы в плагиоклазах, могут быть следствием высокой водонасыщенности расплавов.

\section{ОБСУЖДЕНИЕ РЕЗУЛЬТАТОВ}

\section{Составы минералов вулканитов как показатель условий их образования (некоторые общие положения)}

Температурная зависимость изменения состава минералов магматических пород чаще всего используется для выявления трендов кристаллизационной дифференциации соответствующих расплавов. И этот фактор, в первую очередь, мы постараемся оценить при дальнейшем анализе материалов. Существующие представления о большей барофильности шпинелей (особенно их высокоглиноземистых разностей), по сравнению с титаномагнетитами, позволяет различать ассоциации, кристаллическая фаза которых начинает появляться на разноглубинных уровнях (см. рис. 3a) [Колосков и др., 2001]. С другой стороны, появление титаномагнетитов свидетельствует о малоглубинной и существенно окислитель- ной обстановке формирования пород, также как и образование шпинелей - о более восстановительных условиях. Как видно на рис. 3, при значениях $\mathrm{F} / \mathrm{FM}>80$ происходит резкое возрастание степени окисленности большой группы титаномагнетитов. Показательно, что в тех же составах наблюдается такое же резкое возрастание содержаний $\mathrm{MnO}$ и $\mathrm{TiO}_{2}$. Можно предположить, что подобная зависимость проявляется и в составах других минералов (для $\mathrm{MnO}$ в оливинах, а для $\mathrm{MnO}$ и $\mathrm{TiO}_{2}$ в клинопироксенах) как следствие повышенной фугитивности кислорода. Ранняя и обильная кристаллизация титаномагнетитов, а также железистых и титанистых амфиболов нарушает общий баланс составов в сторону понижения содержания железа (в первую очередь $\mathrm{FeO}$ ) в сосуществующих минералах, что может выразиться в повышении их магнезиальности, а также изоморфном замещении $\mathrm{FeO}-\mathrm{MnO}$. Отсюда следует вывод, что повышенная магнезиальность и высокие содержания марганца в оливинах или пироксенах могут быть показателем кристаллизации минералов в водонасыщенной и окислительной обстановке. Сходные выводы были сделаны при анализе условий образования клинопироксенов в кислых вулканитах Узон-Гейзерного района Камчатки [Гриб, 1997]. С повышенной фугитивностью кислорода и ранней кристаллизацией титаномагнетитов может быть связана и обратная зональность в характере железо-магниевого отношения в силикатах при понижении температуры [Мартынов, Чубаров, 1982]. Существуют и экспериментальные подтверждения [Speidel, Nofriger, 1968], что содержание $\mathrm{MgO}$ в оливине в парагенезисе с магнетитом возрастает с ростом $f_{\mathrm{O}_{2}}$ и понижением температуры.

На базе экспериментальных исследований сложилось представление [Рингвуд, 1981] о том, что в условиях повышенной обводненности расплавов из андезитовой магмы происходит кристаллизация плагиоклазов более известковистых по сравнению с кристаллизацией в безводных условиях. По данным [Feeley, Dungan, 1996; Panjasawatwong et al., 1995] содержание анортитового компонента в плагиоклазе определяется валовым химическим составом породы и концентрацией воды в расплаве. Поэтому аномальное превышение модального состава плагиоклаза над нормативным (при умеренной щелочности и отсутствии признаков смешения расплавов) можно трактовать как свидетельство повышенной обводненности расплавов. Это несоответствие составов плагиоклазов также может нарушить общий баланс компонентов, создавая дефицит СаO и $\mathrm{Al}_{2} \mathrm{O}_{3}$, но избыток $\mathrm{SiO}_{2}$ и привести к тому, что сосуществующие оливины будут обедняться $\mathrm{CaO}$, а вместе с низкокальциевыми и низкоглиноземистыми клинопироксенами будут кристаллизо- 


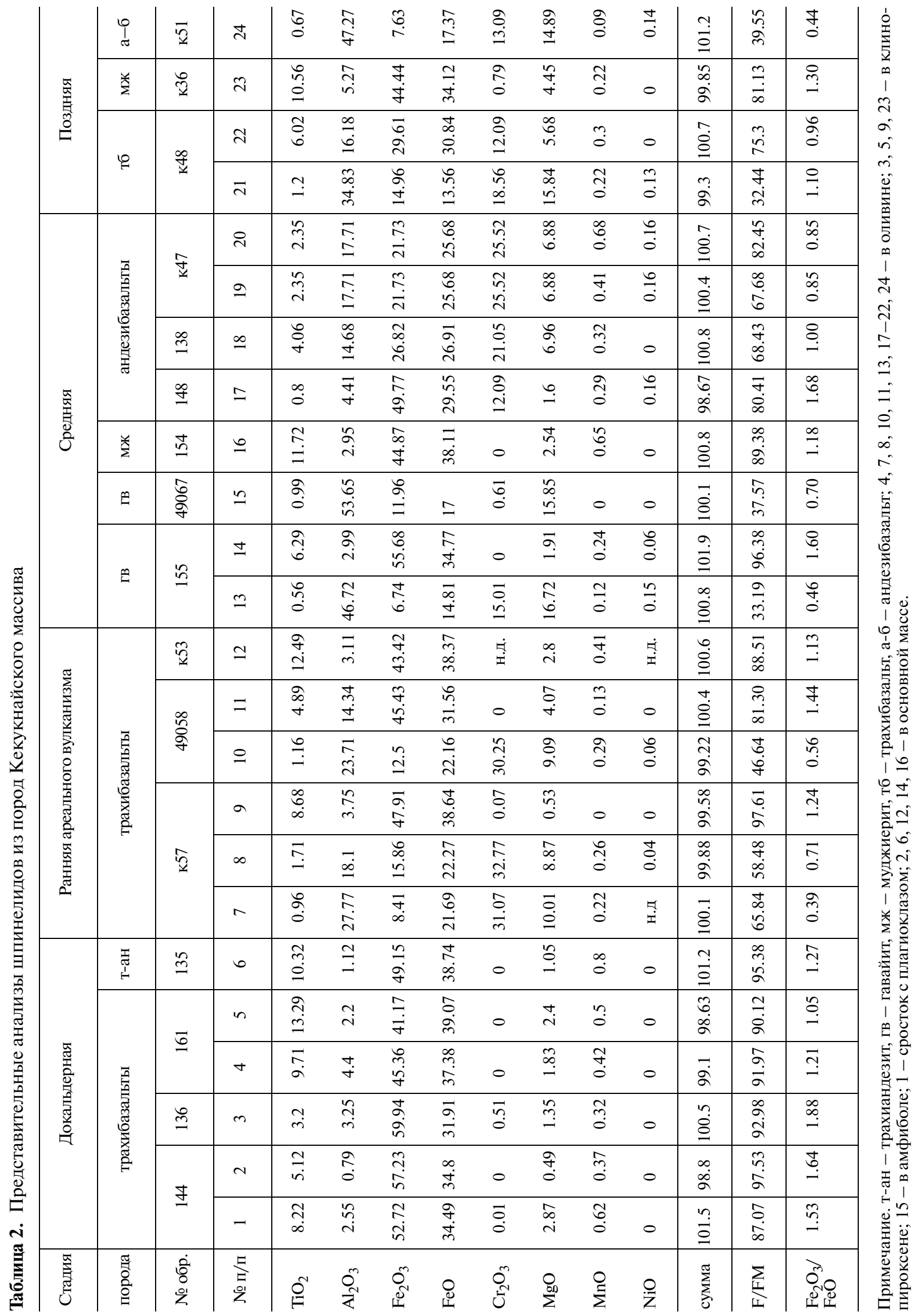

ВУЛКАНОЛОГИЯ И СЕЙСМОЛОГИЯ № 22013 


\begin{tabular}{|c|c|c|c|c|c|c|c|c|c|c|c|}
\hline \multirow{4}{*}{ 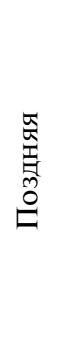 } & $\begin{array}{l}0 \\
1 \\
\sigma\end{array}$ & $\overrightarrow{6}$ & $\stackrel{\sim}{\sim}$ & $\underset{\infty}{=}$ & $\begin{array}{l}\infty \\
\ddot{i} \\
\ddot{a}\end{array}$ & $\begin{array}{l}\vec{\sigma} \\
\stackrel{\sim}{ } \\
\end{array}$ & $\stackrel{m}{0}$ & $\stackrel{m}{0}$ & $\stackrel{0}{0}$ & $\stackrel{\overbrace{}}{\varrho}$ & $\begin{array}{l}\infty \\
0 \\
0\end{array}$ \\
\hline & $\frac{\ldots}{\partial}$ & $\tilde{\check{1}}$ & $\tilde{\lambda}$ & 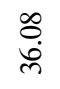 & $\begin{array}{l}\vec{m} \\
\stackrel{q}{q}\end{array}$ & $\overrightarrow{\vec{n}}$ & 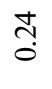 & $\bar{a}$ & & 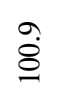 & $\begin{array}{l}\stackrel{n}{\hat{B}} \\
i n\end{array}$ \\
\hline & \multirow{2}{*}{$\begin{array}{l}0 \\
1 \\
t\end{array}$} & \multirow{2}{*}{$\stackrel{\infty}{ \pm}$} & $\approx$ & 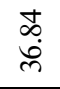 & $\begin{array}{l}\stackrel{0}{0} \\
\text { లె }\end{array}$ & $\frac{n}{\ddot{i}}$ & $\dot{0}$ & $\sqrt[n]{n}$ & 0 & $\begin{array}{l}\circ \\
\swarrow 2 \\
\alpha\end{array}$ & $\stackrel{+}{i}$ \\
\hline & & & $\vec{\sim}$ & $\begin{array}{l}\stackrel{\imath}{0} \\
\infty \\
m\end{array}$ & $\begin{array}{l}\ddot{n} \\
\ddot{n} \\
\dot{n}\end{array}$ & $\begin{array}{l}\overrightarrow{\tilde{n}} \\
\text { D. }\end{array}$ & ָิ & $\stackrel{\text { ڤn }}{3}$ & 0 & $\begin{array}{l}0 \\
\stackrel{8}{8}\end{array}$ & 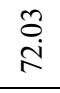 \\
\hline \multirow{8}{*}{ 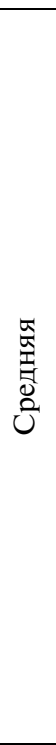 } & \multirow{2}{*}{ 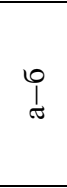 } & ले & ते & $\begin{array}{l}\underset{\sim}{\tilde{m}} \\
\infty \\
\infty\end{array}$ & $\begin{array}{l}\text { よे } \\
\dot{d}\end{array}$ & $\begin{array}{l}\stackrel{?}{2} \\
\stackrel{\sim}{m}\end{array}$ & $\frac{n}{0}$ & 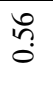 & ஜ্ণ & $\begin{array}{l}\text { बे } \\
\text { बे }\end{array}$ & $\stackrel{\infty}{+}$ \\
\hline & & $\stackrel{\infty}{ \pm}$ & 2 & $\stackrel{\circ}{\stackrel{m}{m}}$ & 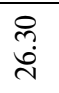 & $\begin{array}{l}\hat{\sigma} \\
\dot{m}\end{array}$ & $\frac{ \pm}{0}$ & $\widehat{\widehat{o}}$ & $\ddot{\circ}$ & $\begin{array}{l}\stackrel{n}{ } \\
\infty \\
\infty\end{array}$ & $\stackrel{\infty}{i}$ \\
\hline & \multirow{2}{*}{$\frac{\breve{x}}{2}$} & \multirow{2}{*}{$\stackrel{\sim}{n}$} & $\stackrel{\infty}{-}$ & $\begin{array}{c}\vec{S} \\
\stackrel{m}{m}\end{array}$ & $\vec{m}$ & $\begin{array}{l}\infty \\
\stackrel{\sim}{\sim} \\
\stackrel{1}{*}\end{array}$ & $\stackrel{0}{0}$ & gे & $\stackrel{8}{0}$ & $\begin{array}{l}\infty \\
\infty \\
\alpha\end{array}$ & $\begin{array}{l}\hat{m} \\
\infty \\
i\end{array}$ \\
\hline & & & $=$ & 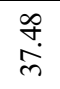 & $\begin{array}{l}\vec{\infty} \\
\vec{\omega}\end{array}$ & $\begin{array}{l}\hat{N} \\
\ddot{n}\end{array}$ & $\frac{0}{0}$ & ?ִ & 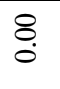 & $\stackrel{m}{8}$ & $\bar{a}$ \\
\hline & \multirow{2}{*}{$\mathscr{\Xi}$} & \multirow{2}{*}{ in } & $\varrho$ & 亏్రి & $\begin{array}{l}\text { ¿े } \\
\text { ठे }\end{array}$ & $\stackrel{\vec{p}}{\dot{m}}$ & 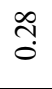 & $\stackrel{\Re}{\tilde{o}}$ & $\stackrel{8}{0}$ & $\stackrel{0}{8}$ & $\begin{array}{l}\stackrel{8}{\circ} \\
\dot{b}\end{array}$ \\
\hline & & & $\cong$ & $\begin{array}{l}\hat{n} \\
\hat{n}\end{array}$ & $\begin{array}{l}\vec{\infty} \\
\stackrel{0}{\varrho}\end{array}$ & $\begin{array}{l}\stackrel{\bullet}{0} \\
\vec{\forall}\end{array}$ & $\stackrel{m}{0}$ & $\stackrel{0}{\circ}$ & $\stackrel{n}{0}$ & $\begin{array}{l}\stackrel{\sim}{1} \\
\stackrel{\infty}{ }\end{array}$ & 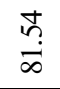 \\
\hline & \multirow{2}{*}{$\mathscr{\forall}$} & \multirow{2}{*}{$\tilde{n}$} & \pm & $\begin{array}{l}\forall \\
\dot{d}\end{array}$ & $\begin{array}{l}\text { oे } \\
\text { in }\end{array}$ & $\begin{array}{l}\text { ָे } \\
\stackrel{\nu}{ }\end{array}$ & $\stackrel{\simeq}{\circ}$ & $\stackrel{\infty}{\circ}$ & $\stackrel{8}{0}$ & 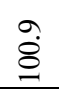 & $\begin{array}{l}\infty \\
\infty \\
i n\end{array}$ \\
\hline & & & 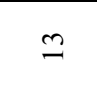 & $\stackrel{n}{\stackrel{n}{m}}$ & $\hat{\grave{\partial}}$ & $\stackrel{亏}{\exists}$ & $\stackrel{\overbrace{}}{0}$ & 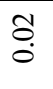 & $\tilde{\overbrace{}}$ & 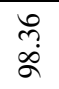 & $\begin{array}{l}\dot{\$} \\
\stackrel{+}{+}\end{array}$ \\
\hline \multirow{6}{*}{ 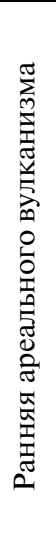 } & \multirow{6}{*}{ 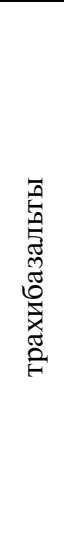 } & \multirow{2}{*}{$\tilde{\hat{n}}$} & $\simeq$ & $\begin{array}{l}\hat{n} \\
\hat{n}\end{array}$ & $\stackrel{\vec{n}}{\stackrel{\sim}{v}}$ & $\vec{m}$ & 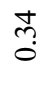 & $\stackrel{3}{0}$ & 8 & $\frac{\infty}{a}$ & 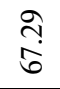 \\
\hline & & & $=$ & $\begin{array}{l}\infty \\
\stackrel{n}{n} \\
\stackrel{n}{n}\end{array}$ & $\begin{array}{l}\stackrel{n}{n} \\
\stackrel{\sim}{\sim}\end{array}$ & $\stackrel{\sim}{\stackrel{m}{m}}$ & 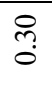 & $\stackrel{8}{\circ}$ & $\stackrel{8}{\circ}$ & $\frac{m}{a}$ & $\begin{array}{l}\underset{0}{\tilde{\delta}} \\
\stackrel{0}{0}\end{array}$ \\
\hline & & \multirow{2}{*}{$\begin{array}{l}\infty \\
\ddot{o} \\
o \\
o\end{array}$} & 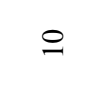 & $\begin{array}{l}\bar{n} \\
\infty \\
\infty\end{array}$ & $\begin{array}{l}\stackrel{+}{o} \\
\dot{ \pm}\end{array}$ & $\begin{array}{l}\hat{a} \\
\dot{y}\end{array}$ & 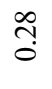 & $\overline{0}$ & $\frac{1}{0}$ & $\begin{array}{l}\widehat{\alpha} \\
\widehat{\alpha}\end{array}$ & $\begin{array}{l}\dot{8} \\
\dot{\infty}\end{array}$ \\
\hline & & & $a$ & $\begin{array}{l}\infty \\
\underset{\infty}{\infty} \\
\infty\end{array}$ & 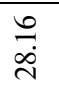 & $\underset{m}{\mathbb{m}}$ & $\vec{m}$ & $\tilde{n}$ & 8 & 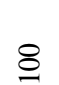 & $\begin{array}{l}\overline{8} \\
\hat{\sigma}\end{array}$ \\
\hline & & \multirow{2}{*}{$\hat{n}$} & $\infty$ & $\begin{array}{l}\text { मे } \\
\text { ले }\end{array}$ & $\begin{array}{l}\dot{D} \\
\dot{\omega} \\
\dot{\omega}\end{array}$ & $\begin{array}{r}\hat{\gamma} \\
\grave{\gamma}\end{array}$ & $\frac{0}{6}$ & 0 & $\frac{5}{0}$ & $\begin{array}{l}\dot{d} \\
\stackrel{\alpha}{\alpha}\end{array}$ & $\begin{array}{l}0 \\
\infty \\
\infty \\
\infty\end{array}$ \\
\hline & & & $r$ & 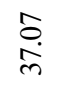 & స్ & 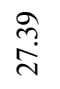 & ஸి & $\bar{n}$ & 0 & $\stackrel{n}{\varrho}$ & $\underset{i}{\stackrel{+}{n}}$ \\
\hline \multirow{6}{*}{ 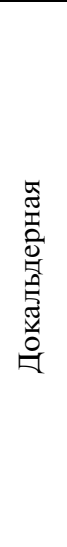 } & \multirow{6}{*}{ 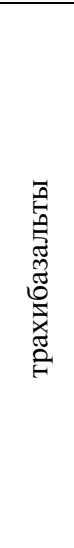 } & \multirow{2}{*}{ 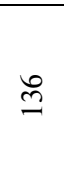 } & 6 & $\begin{array}{l}\Delta \\
\stackrel{0}{0} \\
\infty \\
\infty\end{array}$ & $\begin{array}{l}\text { I. } \\
\text { aे }\end{array}$ & 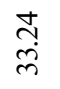 & $\overrightarrow{\widehat{\sigma}}$ & $\stackrel{\circ}{n}$ & 8 & $\stackrel{n}{\varrho}$ & 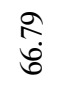 \\
\hline & & & in & $\begin{array}{c}\forall \\
\stackrel{+}{m}\end{array}$ & $\begin{array}{l}\text { Oे } \\
\text { ळे }\end{array}$ & $\begin{array}{l}\tilde{b} \\
\dot{d}\end{array}$ & $\frac{\infty}{0}$ & $\hat{\sigma}$ & 8 & $\stackrel{\circ}{\circ}$ & $\begin{array}{l}\text { ị } \\
\text { in }\end{array}$ \\
\hline & & $\overline{6}$ & $\nabla$ & $\begin{array}{l}\infty \\
\infty \\
\infty \\
\infty\end{array}$ & 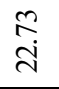 & $\begin{array}{l}\vec{n} \\
\infty \\
\infty\end{array}$ & $\stackrel{ \pm}{0}$ & $\stackrel{\infty}{\stackrel{\infty}{0}}$ & 8 & $\bar{\Xi}$ & $\frac{i}{2}$ \\
\hline & & $=$ & $m$ & 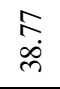 & $\begin{array}{l}\text { ర్ } \\
\text { ते }\end{array}$ & $\underset{\vec{m}}{\vec{m}}$ & $\stackrel{n}{0}$ & $\tilde{\sigma}$ & $\stackrel{8}{0}$ & $\begin{array}{l}0 \\
\text { aे }\end{array}$ & $\begin{array}{l}+ \\
\stackrel{+}{+} \\
\end{array}$ \\
\hline & & $F$ & $\sim$ & 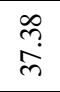 & $\begin{array}{l}\text { तิ } \\
\text { ते }\end{array}$ & $\overrightarrow{\dot{0}}$ & $\frac{\infty}{0}$ & ڤִ & 8 & $\stackrel{\dot{8}}{\circ}$ & 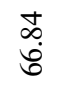 \\
\hline & & $\checkmark$ & - & $\begin{array}{l}\text { 宂 } \\
\stackrel{q}{q}\end{array}$ & $\begin{array}{l}\stackrel{+}{m} \\
\stackrel{n}{n}\end{array}$ & $\begin{array}{l}\tilde{y} \\
\tilde{\gamma}\end{array}$ & ণุ & gे & $\begin{array}{l} \pm \\
\end{array}$ & $\begin{array}{l}\text { ते } \\
\text { ลू }\end{array}$ & $\begin{array}{c}q \\
\dot{\infty} \\
\dot{\infty}\end{array}$ \\
\hline 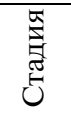 & 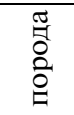 & $\begin{array}{l}\text { 8े } \\
0 \\
\text { on }\end{array}$ & 只是 & $\delta_{i=1}^{N}$ & 这 & $\stackrel{0}{\infty}$ & $\tilde{U}^{\pi}$ & $\sum_{\Sigma}^{J}$ & $\stackrel{\circ}{Z}$ & $\sum_{0}^{\pi}$ & 오 \\
\hline
\end{tabular}




\begin{tabular}{|c|c|c|c|c|c|c|c|c|c|c|c|c|c|c|c|c|}
\hline \multirow{4}{*}{ 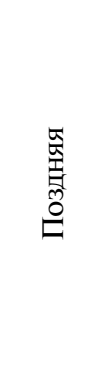 } & $\begin{array}{l}0 \\
1 \\
\sigma\end{array}$ & $\bar{\Xi}$ & $\stackrel{\sim}{\sim}$ & $\underset{g}{\stackrel{d}{b}}$ & $\stackrel{\vec{i}}{i}$ & $\stackrel{\infty}{\stackrel{\infty}{r}}$ & $\begin{array}{l}\stackrel{\circ}{0} \\
\stackrel{0}{9}\end{array}$ & $\stackrel{8}{\circ}$ & $\begin{array}{l}\hat{b} \\
\dot{g}\end{array}$ & $\begin{array}{l}\vec{\forall} \\
\stackrel{\infty}{-}\end{array}$ & 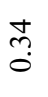 & $\stackrel{t}{0}$ & $\stackrel{\tilde{o}}{\dot{0}}$ & $\begin{array}{l}0 \\
\infty \\
\infty\end{array}$ & 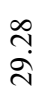 & $\begin{array}{c}0 \\
\text { Oे } \\
1\end{array}$ \\
\hline & $\frac{. 丷}{2}$ & $\stackrel{\varpi}{\dddot{\Xi}}$ & $\ddot{\sim}$ & $\begin{array}{l}n \\
\hat{j} \\
\dot{j}\end{array}$ & $\stackrel{\infty}{\stackrel{\infty}{=}}$ & $\begin{array}{l}\tilde{\sigma} \\
\dot{n}\end{array}$ & సุ. & 8 & $\stackrel{\widetilde{m}}{\stackrel{\sim}{\mathrm{I}}}$ & $\begin{array}{l}\text { 을 } \\
\text { i }\end{array}$ & $?$ & $\begin{array}{l}\tau \\
\delta \\
0\end{array}$ & ô. & $\bar{a}$ & $\begin{array}{l}\hat{n} \\
\text { ते }\end{array}$ & $\begin{array}{l}\Delta \\
\text { a }\end{array}$ \\
\hline & \multirow[b]{2}{*}{ 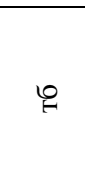 } & \multirow{2}{*}{$\stackrel{\infty}{ \pm}$} & $\widetilde{\curvearrowright}$ & 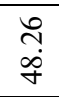 & $\underset{\text { d }}{\stackrel{2}{ }}$ & $\begin{array}{l}\tilde{n} \\
\dot{r}\end{array}$ & 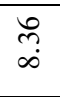 & $\stackrel{8}{\circ}$ & $\begin{array}{l}\stackrel{f}{2} \\
\stackrel{2}{2}\end{array}$ & $\underset{\vec{i}}{\vec{i}}$ & $\stackrel{n}{o}$ & $\begin{array}{l}8 \\
0 \\
0\end{array}$ & $\stackrel{0}{0}$ & $\stackrel{\alpha}{\infty}$ & 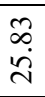 & \\
\hline & & & $\bar{\sim}$ & $\begin{array}{l}\text { बे } \\
\text { }\end{array}$ & $\stackrel{n}{n}$ & 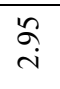 & $\widehat{\widehat{N}}$ & $\stackrel{8}{\circ}$ & $\begin{array}{l}\dot{\eta} \\
\dot{g}\end{array}$ & 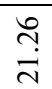 & $\underset{ت}{ \pm}$ & $\begin{array}{l}\text { to } \\
\end{array}$ & $\stackrel{8}{\circ}$ & ๙ั & $\begin{array}{l}\text { 吕 } \\
\dot{d}\end{array}$ & \\
\hline \multirow{7}{*}{ 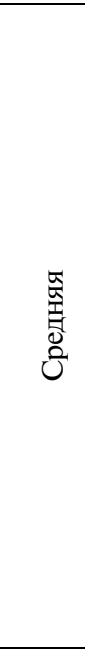 } & \multirow{3}{*}{ 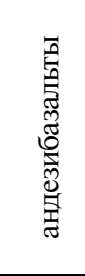 } & ले & $\stackrel{\sim}{~}$ & $\begin{array}{l}\text { f } \\
\stackrel{g}{q}\end{array}$ & $\stackrel{n}{\longrightarrow}$ & $\widehat{\widehat{C}}$ & $\begin{array}{l}\tilde{n} \\
\end{array}$ & $\stackrel{\vartheta}{0}$ & 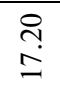 & $\begin{array}{l}\tilde{\sigma} \\
\dot{\Omega}\end{array}$ & $\vec{i}$ & 䓪 & $\stackrel{\text { ?f }}{\circ}$ & ণֶ. & $\begin{array}{c}\tilde{m} \\
\text { mे } \\
m\end{array}$ & \\
\hline & & $\stackrel{\infty}{\rightarrow}$ & 9 & $\vec{m}$ & $\stackrel{N}{0}$ & $\underset{F}{\exists}$ & $\underset{ن}{8}$ & $\tilde{\tilde{\sigma}}$ & $\begin{array}{l}\stackrel{f}{f} \\
\dot{\Xi}\end{array}$ & $\stackrel{n}{\sim}$ & त̂̀ & $\stackrel{8}{0}$ & 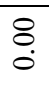 & $\hat{\infty}$ & 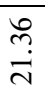 & \\
\hline & & $\stackrel{\infty}{+}$ & 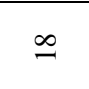 & $\frac{n}{a}$ & $\stackrel{m}{=}$ & $\begin{array}{l}\overrightarrow{+} \\
\stackrel{0}{\circ}\end{array}$ & $\underset{\sim}{ }$ & $\stackrel{8}{\circ}$ & $\begin{array}{l}\text { ले } \\
\stackrel{0}{0}\end{array}$ & $\begin{array}{l}8 \\
\stackrel{8}{1} \\
\ddot{1}\end{array}$ & $\begin{array}{l}\infty \\
\stackrel{\leftrightarrow}{0} \\
\text { i }\end{array}$ & in & $\stackrel{8}{\circ}$ & $\begin{array}{l}\infty \\
\infty \\
\infty \\
\alpha\end{array}$ & $\frac{n}{a}$ & \\
\hline & 关 & 壳 & $=$ & $\begin{array}{l}n \\
0 \\
0 \\
0\end{array}$ & $\vec{b}$ & 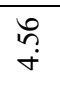 & $\hat{a}$ & $\stackrel{8}{\circ}$ & $\begin{array}{l}\infty \\
\infty \\
\end{array}$ & $\begin{array}{l}\stackrel{\infty}{\infty} \\
\stackrel{\sim}{\sim}\end{array}$ & $\begin{array}{l}\text { m. } \\
\vdots \\
0\end{array}$ & $\ddot{0}$ & 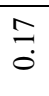 & $\overrightarrow{\dot{D}}$ & 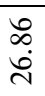 & \\
\hline & $\stackrel{\infty}{0}$ & 모 & $\underline{0}$ & $\begin{array}{l}\hat{n} \\
\hat{q}\end{array}$ & $\stackrel{\Xi}{ت}$ & $\underset{f}{\stackrel{f}{f}}$ & $\underset{\infty}{ \pm}$ & $\stackrel{8}{\circ}$ & $\begin{array}{l}\vec{b} \\
\dot{I}\end{array}$ & $\stackrel{\check{\alpha}}{\Omega}$ & in & $\tilde{\delta}$ & $\overrightarrow{7}$ & $\begin{array}{l}n \\
\infty \\
\infty\end{array}$ & $\begin{array}{l}\tilde{\infty} \\
\stackrel{\sim}{\vec{\lambda}}\end{array}$ & \\
\hline & \multirow[b]{2}{*}{$\underline{\varphi}$} & \multirow[b]{2}{*}{$\stackrel{n}{n}$} & 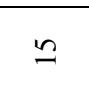 & $\begin{array}{l}\infty \\
\infty \\
\dot{f}\end{array}$ & $\begin{array}{l}\infty \\
\stackrel{\infty}{0} \\
i\end{array}$ & $\begin{array}{l}\vec{\tilde{}} \\
\stackrel{0}{ }\end{array}$ & $\underset{⿱}{\stackrel{ \pm}{r}}$ & $\stackrel{8}{\circ}$ & $\begin{array}{l}\infty \\
\stackrel{\infty}{u} \\
\end{array}$ & $\stackrel{\stackrel{\infty}{+}}{\sim}$ & $\begin{array}{l}\infty \\
n \\
n\end{array}$ & $\stackrel{m}{0}$ & $\stackrel{8}{0}$ & 豖 & $\begin{array}{l}\stackrel{+}{+} \\
\stackrel{+}{\sim}\end{array}$ & \\
\hline & & & $\Xi$ & $\begin{array}{l}\text { g } \\
\text { in }\end{array}$ & $\hat{\jmath}$ & $\underset{i}{\stackrel{N}{i}}$ & $\underset{\sim}{\stackrel{m}{r}}$ & $\stackrel{\sigma}{0}$ & $\begin{array}{l}n \\
2 \\
n\end{array}$ & $\underset{\stackrel{f}{i}}{\mathrm{i}}$ & ô. & $\overrightarrow{0}$ & $\tilde{o}_{0}$ & $\stackrel{m}{\alpha}$ & 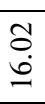 & \\
\hline \multirow{6}{*}{ 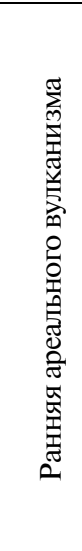 } & $\begin{array}{l}0 \\
1 \\
\sigma\end{array}$ & in & 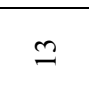 & $\begin{array}{l}n \\
\dot{\sigma} \\
\dot{\gamma}\end{array}$ & $\stackrel{尺}{S}$ & 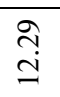 & $\hat{n}$ & $\stackrel{8}{\circ}$ & $\begin{array}{l}\stackrel{\infty}{\stackrel{\infty}{9}} \\
\stackrel{0}{0}\end{array}$ & 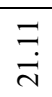 & $\stackrel{m}{0}$ & $\stackrel{8}{\circ}$ & $\stackrel{8}{\circ}$ & $\stackrel{\alpha}{\alpha}$ & $\stackrel{n}{m}$ & \\
\hline & \multirow{5}{*}{ 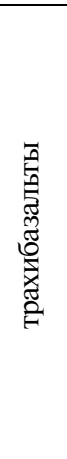 } & \multirow{2}{*}{$\tilde{2}$} & $\simeq$ & 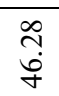 & $\stackrel{\infty}{\infty}$ & $\begin{array}{l}\mathcal{f} \\
\infty \\
\infty\end{array}$ & $\stackrel{8}{\circ}$ & $\begin{array}{l}8 \\
0 \\
0\end{array}$ & $\vec{m}$ & 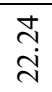 & ơ & $\ddot{0}$ & $\stackrel{8}{8}$ & $\begin{array}{l}\text { o̊ } \\
\text { g. }\end{array}$ & $\begin{array}{l}\text { m. } \\
\dot{i}\end{array}$ & \\
\hline & & & $=$ & $\underset{i}{\stackrel{m}{i n}}$ & $\hat{o}$ & $\stackrel{\Re}{i}$ & $\begin{array}{l}\tilde{N} \\
\underset{\infty}{*}\end{array}$ & 8 & $\begin{array}{l}\stackrel{2}{2} \\
\stackrel{2}{2}\end{array}$ & $\begin{array}{l}\text { ते } \\
\text { ते }\end{array}$ & $\begin{array}{l}\infty \\
\infty \\
0 \\
0\end{array}$ & $\begin{array}{l} \\
\\
0\end{array}$ & $\vec{\sigma}$ & $\begin{array}{l} \\
\dot{8} \\
\dot{8}\end{array}$ & $\begin{array}{l}\infty \\
\infty \\
\dot{n}\end{array}$ & \\
\hline & & \multirow{2}{*}{ 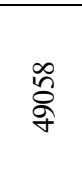 } & 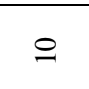 & 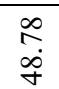 & $\stackrel{\rho}{0}$ & $\begin{array}{l}\vec{b} \\
\dot{n}\end{array}$ & 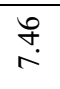 & $\begin{array}{l}0 \\
\stackrel{0}{0}\end{array}$ & $\begin{array}{l}\stackrel{q}{+} \\
\dot{m}\end{array}$ & $\overrightarrow{\bar{n}}$ & $\frac{ \pm}{0}$ & $\tilde{\sim}$ & $\underset{0}{0}$ & $\begin{array}{l}\circ \\
\infty\end{array}$ & $\begin{array}{l}\stackrel{\nabla}{\vec{v}} \\
\vec{\lambda}\end{array}$ & \\
\hline & & & $a$ & $\begin{array}{l}\stackrel{0}{2} \\
\dot{y}\end{array}$ & $\stackrel{8}{8}$ & $\Xi$ & $\begin{array}{l}\hat{\sigma} \\
\dot{\gamma}\end{array}$ & 8 & $\begin{array}{l}\tilde{N} \\
\end{array}$ & 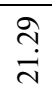 & ợ & ते & 8 & $\underset{\infty}{\stackrel{+}{\sigma}}$ & 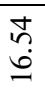 & \\
\hline & & i & $\infty$ & $\begin{array}{l}n \\
\stackrel{n}{8}\end{array}$ & $\stackrel{n}{\longrightarrow}$ & $\stackrel{\infty}{\stackrel{+}{+}}$ & $\begin{array}{l}\infty \\
\infty \\
\sigma\end{array}$ & $\exists$ & $\begin{array}{l}\infty \\
\stackrel{m}{n}\end{array}$ & $\begin{array}{l}\hat{0} \\
\stackrel{i}{i}\end{array}$ & ñ & $\stackrel{\square}{\circ}$ & $\stackrel{8}{0}$ & $\begin{array}{l}\infty \\
\alpha \\
\alpha\end{array}$ & $\stackrel{\infty}{\stackrel{i}{\hat{i}}}$ & \\
\hline \multirow{7}{*}{ 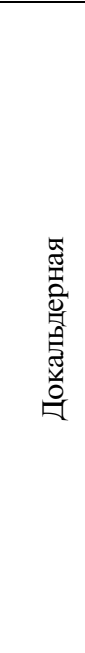 } & 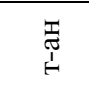 & $\approx$ & r & $\stackrel{\Re}{\stackrel{f}{f}}$ & $\stackrel{\Upsilon}{\Im}$ & 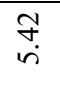 & $\begin{array}{l}\overrightarrow{\widetilde{O}} \\
\stackrel{0}{ }\end{array}$ & $\begin{array}{l}8 \\
0\end{array}$ & $\begin{array}{l}\stackrel{\circ}{n} \\
\stackrel{\sim}{I}\end{array}$ & $\begin{array}{l}\text { I } \\
\infty \\
\stackrel{\sim}{\sim}\end{array}$ & m. & $\stackrel{0}{0}$ & 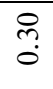 & $\begin{array}{l}0 \\
\dot{\infty} \\
\alpha\end{array}$ & $\vec{m}$ & \\
\hline & \multirow{6}{*}{ 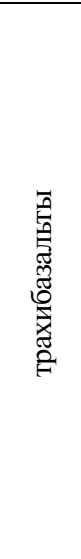 } & \multirow{3}{*}{$\underline{\square}$} & 6 & $\begin{array}{l}\tilde{f} \\
\stackrel{q}{q}\end{array}$ & ڤ̊ & $\stackrel{\mathscr{m}}{\sim}$ & $\stackrel{n}{n}$ & $\begin{array}{l}8 \\
0 \\
0\end{array}$ & $\begin{array}{l}\hat{\infty} \\
\dot{ \pm}\end{array}$ & $\hat{\tilde{n}}$ & $\stackrel{8}{+}$ & 8 & $\stackrel{\circ}{0}$ & & $\begin{array}{l}\vec{\partial} \\
\text { के } \\
\text { i }\end{array}$ & \\
\hline & & & in & $\stackrel{+}{n}$ & $\hat{n}$ & $\hat{\tilde{n}}$ & $\begin{array}{l}0 \\
\text { ñ }\end{array}$ & $\begin{array}{l}8 \\
0\end{array}$ & $\frac{1}{6}$ & $\stackrel{\text { fa }}{\stackrel{\sim}{\sim}}$ & $\widehat{ָ}$ & $\begin{array}{l}8 \\
0\end{array}$ & Oे. & $\begin{array}{l}\infty \\
\stackrel{8}{0} \\
\dot{8}\end{array}$ & $\begin{array}{l}\stackrel{\tilde{N}}{\sim} \\
\stackrel{\sim}{\sim}\end{array}$ & \\
\hline & & & $\nabla$ & $\begin{array}{l}\hat{b} \\
\dot{\sigma}\end{array}$ & $\stackrel{\circ}{\leftrightarrows}$ & $\stackrel{P}{\stackrel{P}{+}}$ & $\begin{array}{l}\tilde{S} \\
\stackrel{0}{0} \\
\end{array}$ & $\stackrel{8}{0}$ & 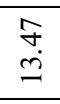 & $\hat{\stackrel{i}{i}}$ & ñ & : & $\stackrel{\circ}{0}$ & $\stackrel{\sigma}{\infty}$ & $\begin{array}{l}\hat{b} \\
\dot{m} \\
\dot{m}\end{array}$ & \\
\hline & & $\stackrel{\overbrace{}}{\approx}$ & $m$ & 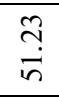 & $\begin{array}{l}\tilde{S} \\
\text { S. }\end{array}$ & $\overline{\widehat{i}}$ & तิ & 8 & $\begin{array}{l}\tilde{n} \\
\dot{ \pm}\end{array}$ & $\vec{\sigma}$ & $\begin{array}{l}\infty \\
\substack{0 \\
0}\end{array}$ & $\tilde{\delta}$ & $\frac{ \pm}{0}$ & $\stackrel{\circ}{\dot{8}}$ & 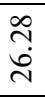 & \\
\hline & & \multirow[b]{2}{*}{-} & $\sim$ & 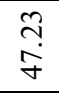 & $\stackrel{\widetilde{I}}{\longrightarrow}$ & $\vec{\pi}$ & $\underset{\sim}{\stackrel{+}{\sim}}$ & $\stackrel{7}{0}$ & 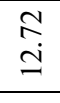 & $\begin{array}{l}\tilde{O} \\
\text { ì }\end{array}$ & $\stackrel{m}{m}$ & $\stackrel{m}{0}$ & 8 & $\underset{m}{m}$ & 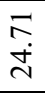 & \\
\hline & & & - & $\begin{array}{l}\text { ô } \\
\text { in }\end{array}$ & f. & $\hat{i}$ & $\stackrel{n}{\infty}$ & $\ddot{0}$ & $\begin{array}{l}\stackrel{2}{2} \\
i n\end{array}$ & 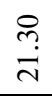 & 。. & $\stackrel{8}{0}$ & $\frac{n}{0}$ & $\stackrel{\circ}{\circ}$ & $\begin{array}{l}\stackrel{\Delta}{\infty} \\
\stackrel{\sim}{N}\end{array}$ & \\
\hline 息罡 & $\begin{array}{l}\frac{1}{2} \\
\stackrel{\circ}{\circ}^{\prime}\end{array}$ & 궁ㅇㅇㅇ & 인콥 & $\stackrel{0}{N}^{N}$ & $\overbrace{\mathscr{H}}^{N}$ & $\ll$ & 足 & 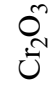 & $\stackrel{0}{\infty}$ & $\tilde{U}$ & $\widetilde{Z}$ & $\stackrel{\circ}{\sim}$ & $\stackrel{\circ}{\xi}$ & 音 & $\sum_{\text {I }}^{\sum_{I}}$ & \\
\hline
\end{tabular}

6 ВУЛКАНОЛОГИЯ И СЕЙСМОЛОГИЯ № 22013 


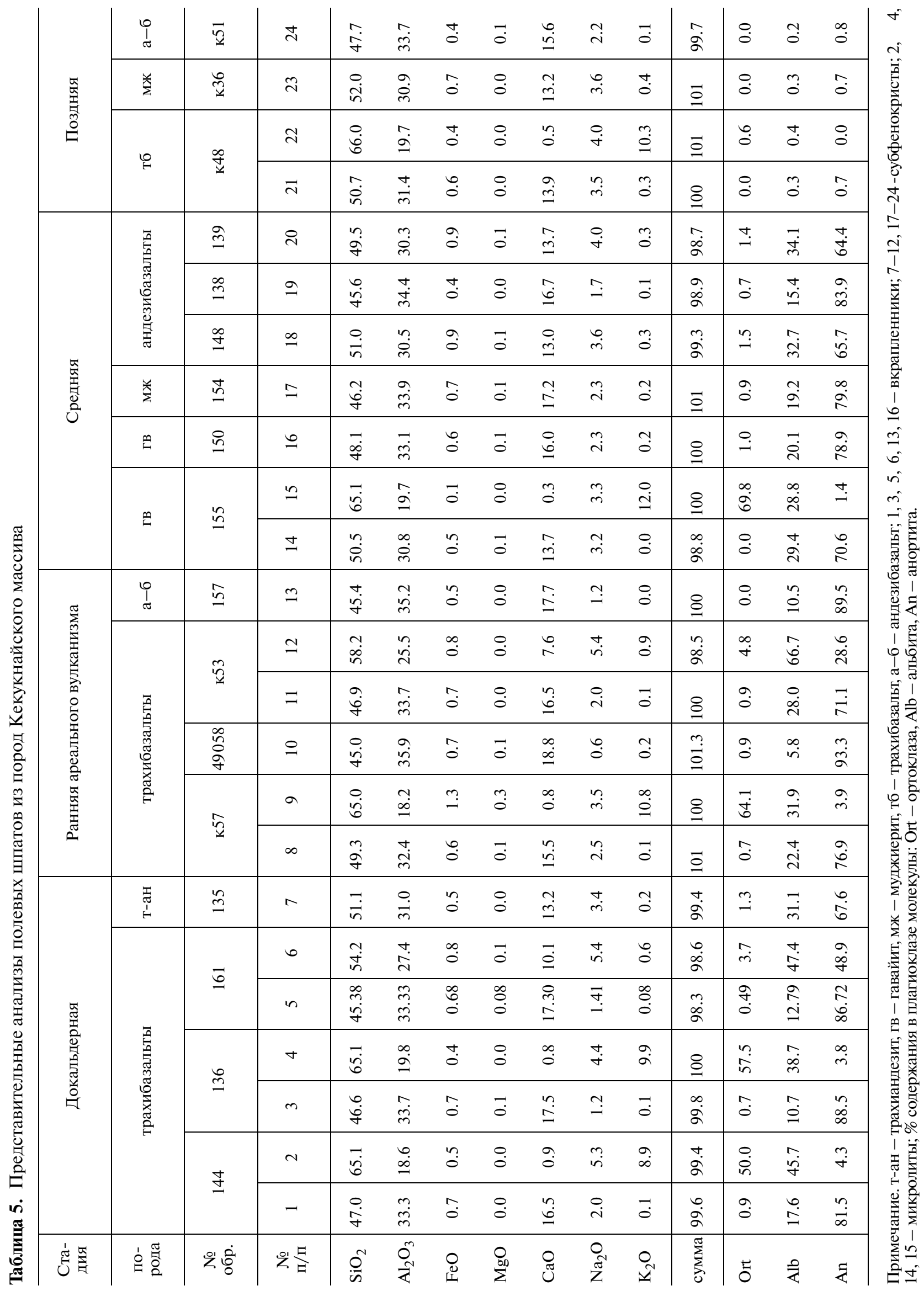


ваться ортопироксены. Совместно с другими известными показателями (наличие амфибола или следов его диссоциации) эти особенности можно также использовать для суждения о высокой водонасыщенности магматических расплавов.

\section{Условия образования ассоциаций пород массива}

Итак, мы имеем в составе Кекукнайского массива пять разновозрастных ассоциаций пород, петролого-геохимические характеристики которых представлены на рис. 2, а основные минералогические показатели - в таблицах, 1-4 и на рисунках 3-8 и 10. Проведем их сравнительный анализ.

Островодужная (орогенная), по своим геохимическим особенностям, трахибазальт-трахидацитовая ассоциация щитообразного вулкана и экструзий (см. рис. 2, I) образовалась в условиях повышенного окислительного потенциала и, вероятно, большой обводненности расплавов, хотя амфибол в виде субфенокристаллов фиксируется только в некоторых экструзивных трахиандезитах и трахидацитах. В качестве включений в самых ранних генерациях оливинов и пироксенов из трахибазальтов постройки присутствуют титаномагнетиты (см. рис. 3, 4, 6), которые сопровождают все стадии кристаллизации пород. Подавляющее большинство титаномагнетитов отличаются высокой окисленностью железа и повышенным содержанием $\mathrm{MnO}$ и $\mathrm{TiO}_{2}$ (см. рис. 3). Аномально высокие по своей магнезиальности, оливины и пироксены обнаружены в более железистых по валовому составу трахибазальтах (см. рис. 4 и 6, обр. 141 и 144 по сравнению с обр. 136 и 161). Большинство оливинов, к тому же, еще обогащены $\mathrm{MnO}$, содержание которого резко возрастает с ростом железистости минерала. Пик обогащения этим компонентом также наблюдается в клинопироксенах (см. рис. 5а и 5б). Для плагиоклазов некоторых трахибазальтов (см. рис. 8, обр. 144 и 136) характерен очень высокий уровень обогащения анортитовой составляющей, который создает дефицит $\mathrm{CaO}$, что выражается в пониженной глиноземистости клинопироксенов некоторых микро-литов (см. рис. 7а), пониженным содержанием $\mathrm{CaO}$ в железистых оливинах и широким развитием ортопироксенов (см. рис. 10а и 10б).

2. Промежуточная по своим геохимическим особенностям трахибазальтовая ассоциация ранней стадии ареального вулканизма характеризуется вертикальным трендом по соотношению $\mathrm{Nb}-\mathrm{K}$ (см. рис. 2a, II), в котором нижняя часть (трахибазальт некка, обр. к53а) и по составу, и по условиям образования, весьма приближена к трахибазальтам докальдерной постройки, а вулканиты верхней части тренда (обр. к57 и 4958 потока шлакового конуса “Заросший”) имеют промежуточный состав между трахибазальтами постройки и ареальными гавайитами. Только для трахиба- зальтов некка предполагается повышенная роль летучих компонентов (в том числе воды) и высокая фугитивность кислорода (титаномагнетитовый контроль, аномалии по $\mathrm{MnO}$ и СаO в оливинах). Для остальных трахибазальтов - явная восстановительная обстановка (контроль хром-алюминиевой шпинели при невысоких содержаниях $\mathrm{MnO}$ в этом минерале и в клинопироксене, хорошая корреляция Fo-MnO и $\mathrm{CaO}-\mathrm{Fo}$ в оливине). Отсутствие амфибола и следов его распада свидетельствует об относительной сухости исходных расплавов. На примере пород конуса “Заросший" можно видеть картину отсутствия эффекта фракционирования расплавов: при чрезвычайно широком диапазоне изменения магнезиальности оливина $\left(\mathrm{Fo}_{86-56}\right)$ в трахибазальтах потока валовый состав пород конуса и потока из него практически одинаков.

3. Промежуточная по составу ассоциация амфиболовых андезибазальтов шлаковых конусов ранней стадии ареального вулканизма имеет такой же близкий к вертикальному тренд соотношения $\mathrm{Nb}-\mathrm{K}$ (см. рис. 2a III), который в верхней своей части как бы продолжается в составах андезибазальтов (обр. к41 и 138) гавайит-муджиеритовой ассоциации (IV) с некоторым сдвигом по калию, а в нижней - обращен в сторону поля пород трахибазальт-трахидацитовой ассоциации. По составам, структурным характеристикам и условиям кристаллизации андезибазальты обеих групп (ассоциации III и I) весьма схожи: титаномагнетитовый контроль, присутствие амфибола или структур его распада, повышенные содержания $\mathrm{MnO}$ в оливинах и клинопироксенах при близкой магнезиальности на тех же уровнях (см. рис. 5а, 5в и 5б, 5г), отрицательная аномалия по СаO в оливинах (см. рис. 10а и 10в), повышенная основность плагиоклаза (см. рис 8, обр. 147 и 157). Все это свидетельствует о высокой обводненности и окисленности расплавов.

4. Внутриплитная по своим геохимическим особенностям гавайит-муджиеритовая (андезибазальтовая) ассоциация средней стадии ареального вулканизма в основе своей образовалась из расплавов с высокой концентрацией расплавно и флюидномобильных компонентов, которые начали кристаллизоваться в условиях шпинель-оливинового равновесия при низкой фугитивности кислорода. В ходе эволюции расплавов существенно меняются концентрации отдельных элементов, а степень водонасыщенности и окисленности возрастает. Происходит образование двух серий пород: 1) гавайит-андезибазальтовой и 2) гавайит-муджиеритовой.

Первая характеризуется наличием субвертикального по соотношению $\mathrm{Nb}-\mathrm{K}$ декомпрессионного тренда с малой обводненностью и низкой фугитивностью кислорода в начале тренда, но с 
возрастанием этих параметров при переходе к андезибазальтам (см. рис. 2a, IV; рис. 2б-г (гавайиты, образцы - 155, 2614, 49065, 150; андезибазальты, образцы - к47, к41, 148, 49064, 139, 138), по мере уменьшения содержания $\mathrm{Nb}$ и возрастания кремнекислотности пород. Кристаллизация расплавов этой ассоциации началась при контроле высокоглиноземистой шпинели и проходила затем с понижением содержания глинозема в этом минерале $\left(\mathrm{Sp}_{\mathrm{Al}_{46-47}} \rightarrow \mathrm{Sp}_{\mathrm{Al}_{23-32}} \rightarrow \mathrm{Sp}_{\mathrm{Al}_{17}} \rightarrow \mathrm{Sp}_{\mathrm{Al}_{13-14}} \rightarrow \mathrm{Sp}_{\mathrm{Al}_{15}}\right)$. Для пород этой группы присутствие амфибола не характерно, за исключением теневых форм распада роговой обманки в одном из некков (обр. 155) и наличия мелких зерен этого минерала (в срастании с клинопироксеном и калишпатом) в андезибазальтах (обр. 49064, 138).

Гавайит-муджиеритовая серия характеризуется наличием коррелятивного по соотношению $\mathrm{Nb}-\mathrm{K}$ тренда (см. рис. 2a, IV; рис. 2б-г, гавайит, обр. 49067, муджиериты, обр. 2751, 152-1, 153, 154), по мере возрастания содержания $\mathrm{Nb}$ и увеличения $\mathrm{SiO}_{2}$ пород, псевдофракционного с большой обводненностью и повышенной фугитивностью кислорода с первых этапов кристаллизации пород. Для пород этой серии характерен ранний шпинель-алюминиевый контроль при наличии вкрапленников амфибола в гавайитах с переходом к титаномагнетитовым парагенезисам с амфиболом в муджиеритах.

Обе серии четко различаются по соотношению $\mathrm{MnO}-\mathrm{Fo}$ (см. рис. 5д) и CaO-Fo в оливинах (см. рис. 10д). Кроме того, клинопироксены андезибазальтов, в отличие от муджиеритов, по соотношению $\mathrm{TiO}_{2}-\mathrm{F} / \mathrm{FM}$ располагаются в поле относительно низкотитанистых безамфиболовых гавайитов (см. рис. 7е). Провести сопоставление амфиболовых гавайитов и муджиеритов по соотношению этих элементов трудно, ввиду резких различий в содержании $\mathrm{TiO}_{2}$ вмещающих пород. Водонасыщенные аномальные муджиериты также отличаются резко завышенными содержаниями анортитовой молекулы плагиоклаза по отношению к нормативному составу (см. рис. 8в, обр. 154).

5. Трахибазальт-гавайит-муджиеритовая ассоциация поздней стадии ареального вулканизма представлена фрагментарно (см. рис. 2, V). Часть трахибазальтов располагается в поле того же типа пород промежуточной ассоциации (поле II) и весьма сходны с ними как по составу, так и по условиям образования. Несколько анализов занимают промежуточное положение между полями II и IV. Гавайиты и муджиериты целиком занимают поле пород одноименного состава ассоциации внутриплитного типа (поле IV) и также весьма близки по многим параметрам к вулканитам этого типа. В целом породы рассматриваемой ассоциации характеризуются отсутствием амфибола и ортопироксена, контролем ранней глино- земистой шпинели, которая в ходе дифференциации пород уступает место титаномагнетитам. Это свидетельствует об относительной сухости исходных расплавов и низкой фугитивности кислорода.

Здесь также можно выделить две серии пород с двумя трендами дифференциации, коррелятивных по соотношению $\mathrm{Nb}-\mathrm{K}$ (см. рис. $2 \mathrm{a})$, но разнонаправленных: 1) гавайит-трахибазальтовую (см. рис. 2б-г, гавайиты: обр. 2627, к43; трахибазальты: обр. 49060, 49061; базальт, обр. к48) - по мере уменьшения содержания $\mathrm{Nb}$ и $\mathrm{SiO}_{2}$ пород, и 2) трахиандезибазальт-муджиеритовую (см. рис. 2бг, андезибазальт 49055; муджиериты: 163, 158, 159, 49051, к36-1, 2602) - по мере возрастания содержания $\mathrm{Nb}$ и $\mathrm{SiO}_{2}$ пород.

Первый тренд является декомпрессионным, судя по уменьшению содержания таких элементов, как $\mathrm{Nb}$ и Та, второй - псевдофракционным, сходным с подобным трендом в ассоциации IV.

Отмечается умеренная обогащенность марганцем оливинов и низкие содержания $\mathrm{MnO}$ в клинопироксенах (см. рис. 5ж и 53) для большей части трахибазальтов и всех андезибазальтов 1-ой серии. В этом плане они сходны с трахибазальтами ранней стадии, гавайитами и андезибазальтами средней стадии ареального вулканизма, образовавшимися при низкой фугитивности кислорода. Оливины муджиеритов более железистые и по высокому $\mathrm{MnO}$ и низкому $\mathrm{CaO}$ (см. рис. 5ж и рис. 10ж) соответствуют окислительной обстановке формирования, такой же как для муджиеритов средней стадии. Фиксируется также аномально повышенная магнезальность клинопироксенов некоторых муджиеритов и андезибазальтов горы Черная (см. рис. 6, обр. 159, 158, к51). Для первых она значимо превышает магнезиальность ранних оливинов (в тех же образцах), и выше, чем в клинопироксенах из муджиеритов средней стадии.

Андезибазальты горы Черная характеризуются повышенной основностью ранних генераций плагиоклаза (см. рис. 8г, обр. к51), что сопровождается пониженным содержанием $\mathrm{CaO}$ в сосуществующих клинопироксенах (см. рис. 10з). По соотношению $\mathrm{TiO}_{2}-\mathrm{SiO}_{2}$ (см. рис. 2в) видно, что при несколько повышенной титанистости (соответствующей высоким содержаниям $\mathrm{Nb}$ ) андезибазальты горы Черная (обр. 2607, 2608, 2609) и “аномальные" муджиериты (обр. 158, 159) значительно обогащены кремнеземом, а муджиериты еще и щелочами (см. рис. 2г), что “выбивает” их из полосы тренда дифференциации соответствующей группы пород. Это обстоятельство, наряду с обильным габброидным ксенолитным материалом, который содержится в породах горы Черная, вероятно, является хорошим свидетельством повышенной роли гибридных разностей пород в составе этой стадии, что отмечалось уже в первой части работы [Колосков и др., 2011]. 

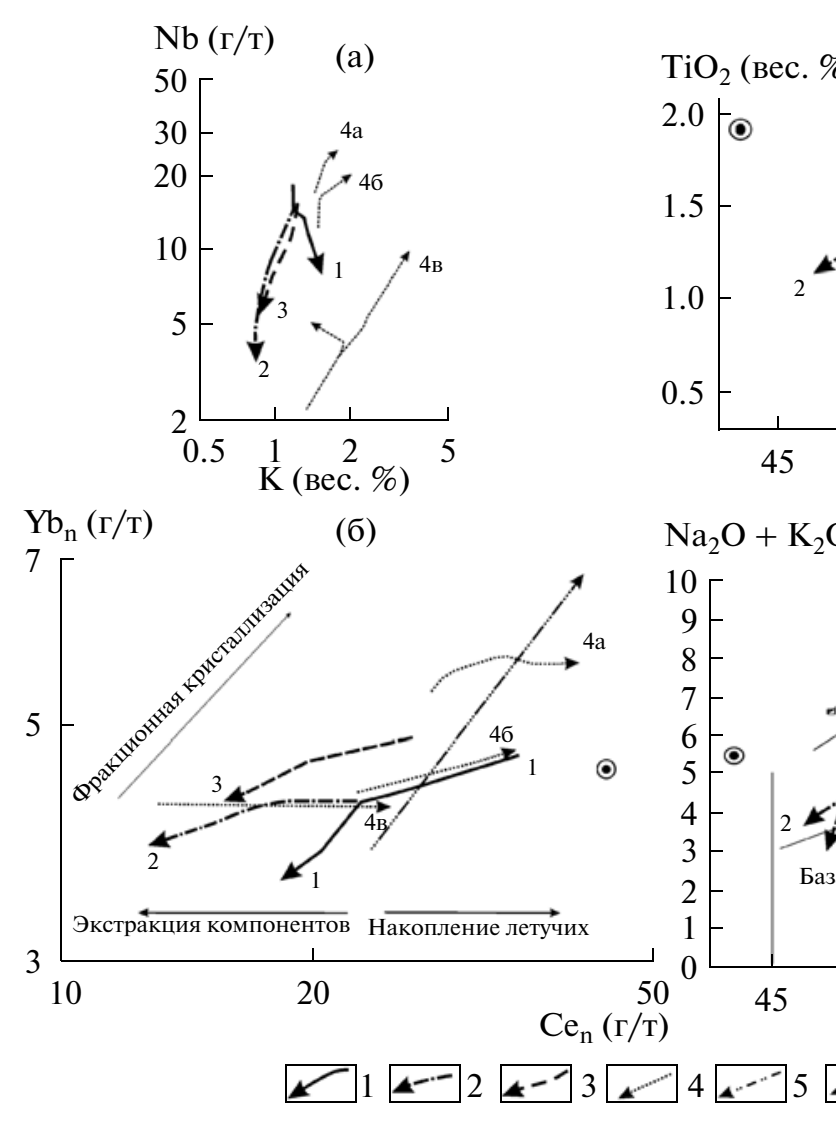

(в)

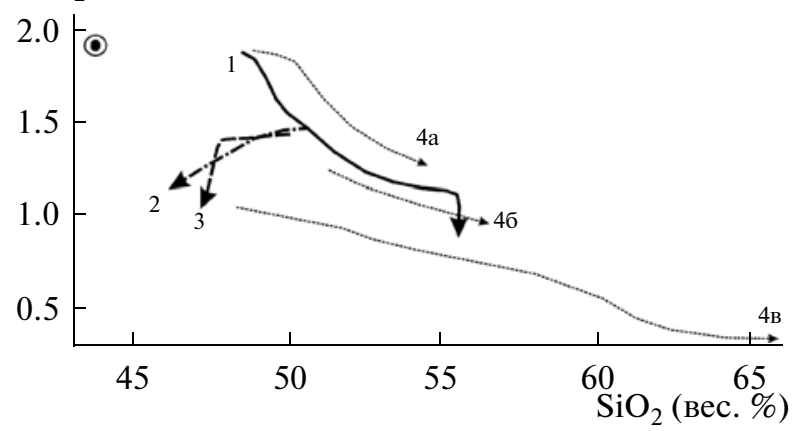

(г)

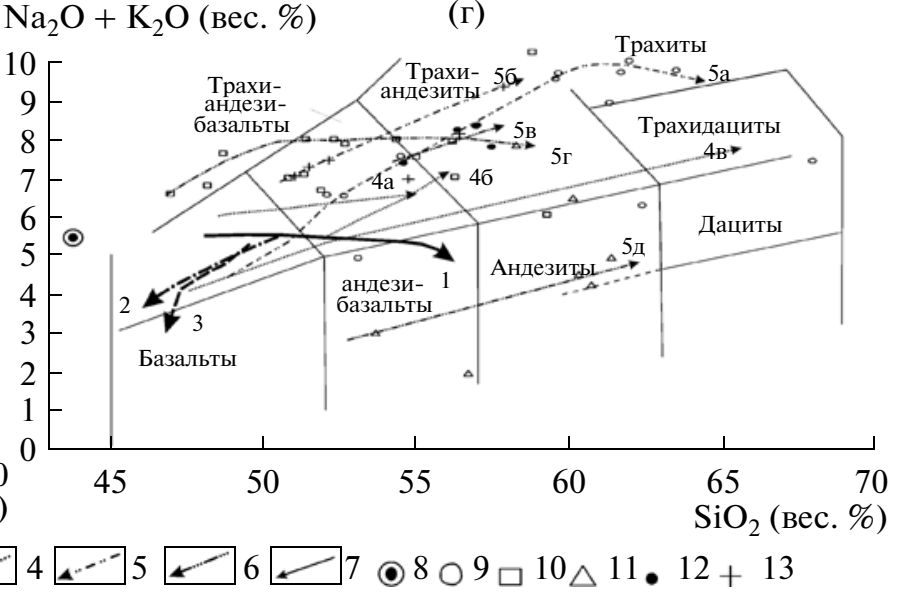

Рис. 11. Предполагаемые тренды эволюции составов расплавов для различных стадий эволюции Кекукнайского массива в координатах: $\mathrm{Nb}-\mathrm{K}(\mathrm{a}), \mathrm{Yb}_{\mathrm{n}}-\mathrm{Ce}_{\mathrm{n}}$ (б), $\mathrm{TiO}_{2}-\mathrm{SiO}_{2}$ (в) и $\mathrm{Na}_{2} \mathrm{O}+\mathrm{K}_{2} \mathrm{O}-\mathrm{SiO}_{2}$ (г).

1-7 - типы трендов: 1-3 - декомпрессионные: 1 - гавайитов-андезибазальтов промежуточной стадии ареального вулканизма и амфиболовых андезибазальтов шлаковых конусов, 2-3: гавайитов-трахибазальтов промежуточной-ранней (2) и поздней (3) стадий ареального вулканизма, 4 - компенсационные гавайитов-муджиеритов: промежуточной (4a) и поздней (4б) стадий ареального вулканизма и трахибазальтов-трахидацитов, докальдерной стадии и экструзий (4в), 5 - расплавных включений в минералах и остаточных стекол из пород: трахибазальтов-трахиандезибазальтов, дацитов, докальдерной стадии и экструзий (5а), амфиболовых андезибазальтов шлаковых конусов (5б, 5д), муджиеритов поздней стадии ареального вулканизма (5в), гавайитов промежуточной стадии (5г); 6 - тренд эволюции расплавов Белоголовского вулкана, 7 - эволюции расплавов при фракционной кристаллизации, экстракции компонентов и накоплении летучи; 8 - предполагаемый состав исходных расплавов; 9-13 - составы расплавных включений в минералах и остаточных стекол из пород: трахибазаль-трахидацитовой ассоциации (9), гавайитов промежуточной стадии (10), андезибазальтов шлаковых конусов (11), муджиеритов конечной стадии (12), андезибазальтов промежуточной стадии ареального вулканизма (13).

$\mathrm{Yb}_{\mathrm{n}}, \mathrm{Ce}_{\mathrm{n}}$ - значения соответствующих компонентов нормированы на их концентрации в пиролите (примитивная мантия) по [Sun, McDonougt, 1989].

\section{Предполагаемая петрологическая модель формирования Кекукнайского массива и петрогенезис магм}

В ходе эволюции расплавов Кекукнайского массива островодужный тип вулканизма сменяется внутриплитным. Оба эти типа обычно противопоставляются друг другу, так как считается, что они имеют разные источники и разный механизм образования. Первый тип связывается с процессами субдукции [Volynets et al., 2010], второй прямо или косвенно - с эволюцией мантийных плюмов [Volynets, 1994]. Тем не менее, существуют работы, в которых подчеркивается генети- ческая связь этих образований [Колосков и др., 2001; Колосков, 2006].

Как показали наши исследования, наиболее существенные различия как в характере дискретных во времени этапов вулканической деятельности, так и петрологии и геохимии ее продуктов наблюдаются для пород докальдерного щитообразного вулкана, с одной стороны, и посткальдерных ареальных проявлений, с другой. В целом, на фоне широких вариаций составов пород массива отмечается выдержанность, линейность корреляционных трендов петрогенных, редких и редкоземельных элементов для трахибазальт трахидацитовой и гавайит - муджиеритовой ас- 
социаций. Представляется, что главную роль в формировании Кекукнайского массива играло участие магм трахибазальтового и гавайитового состава с характерными признаками островодужного и внутриплитного геохимических типов, которые поступали из разноглубинных (промежуточных) магматических очагов, питающих непосредственно вулкан центрального типа и ареальную зону. Не исключается при этом вероятность взаимодействия этих расплавов.

Однако сходство изотопных характеристик для различных типов пород этого массива [Колосков и др., 2011] свидетельствует о едином для них мантийном источнике и позволяет рассматривать их в составе единой флюидно-магматической системы. Более того, анализ этапности и составов отдельных фрагментов (ассоциаций) Кекукнайского массива (см. рис. 2) показывает, что они хорошо дополняют друг друга так, что конечные члены одного ряда находят свое продолжение в начальных составах другого ряда.

В целом петрологическую модель становления массива можно представить в виде системы трендов (рис. 11). Декомпрессионный гавайит-андезибазальтовый тренд средней стадии ареального вулканизма (IV-ой ассоциации) продолжается далее в поле андезибазальтов шлаковых конусов (см. рис. 11, 1), которые отличаются только большей водонасыщенностью и окисленностью соответствующих расплавов. С другой стороны, этот же тренд, вернее его гавайитовую составляющую можно продолжить и в сторону трахибазальтов ранней стадии ареального вулканизма (см. рис. 11, 2), поскольку некоторые гавайиты, по соотношению $\mathrm{TiO}_{2}-\mathrm{SiO}_{2}$, уже отклоняются в эту сторону (см. рис. 2в), а наименее дифференцированные разности пород этой стадии являются промежуточными между трахибазальтами и гавайитами. Кроме того, кристаллизация этих “крайних" трахибазальтов (верхняя часть тренда 2) началась при контроле $\mathrm{Cr}-\mathrm{Al}$ шпинели $\left(\mathrm{Al}_{2} \mathrm{O}_{3}=27-29 \%\right)$ и только в случае наиболее флюидонасыщенных трахибазальтов некка (нижняя часть тренда 2) (обр. к53) идет в условиях магнетитового контроля. Подобную направленность имеет гавайит-трахибазальтовый тренд поздней стадии ареального вулканизма (см. рис. 11, 3). Таким образом, для ареальных вулканитов мы имеем общий декомпрессионный тренд, который в начальной своей части соответствует гавайитам, а затем разветвляется в сторону водонасыщенных андезибазальтов (см. рис. 11, 1), с одной стороны, или недосыщенных в отношении флюидной и, особенно, водной фазы - трахибазальтов (см. рис. 11, 2-3), с другой. При этом характерно наличие общей закономерности: постепенный переход от более глубинного внутриплитного типа пород к малоглубинному островодужному сопровождается последова- тельным уменьшением концентраций индикаторных высокозарядных элементов (Nb, Ta, Zr, Hf), La/Yb-отношения), суммарной щелочности (см. рис. 11г) [Колосков и др., 2011], возрастанием фугитивности кислорода и раскислением расплавов, если это связано с повышением водонасыщенности системы, или повышением основности, если эволюция идет в условиях малой флюидои водонасыщенности. Наблюдается последовательное изменение парагенезисов субликвидусной кристаллизации минералов по схеме: AlSp + $+\mathrm{Ol} \rightarrow \mathrm{CrAlSp} \pm \mathrm{Ol} \pm \mathrm{cPx} \pm \mathrm{oPx} \rightarrow \mathrm{Hb}+\mathrm{mt} \pm \mathrm{Ol} \pm$ $\pm \mathrm{cPx} \pm$ oPx $+\mathrm{Pl}$, либо CrAlSp $\pm \mathrm{Ol}+\mathrm{cPx}+\mathrm{Pl} \pm \mathrm{mt}$.

Помимо декомпрессионных в ходе эволюции рассматриваемой флюидно-магматической системы выделяется еще ряд трендов фракционной направленности (см. рис. 11a-в). Они имеют общую характерную особенность - по мере возрастания кремнекислотности и щелочности пород увеличивается содержание высокозарядных $(\mathrm{Nb}$, $\mathrm{Ta}, \mathrm{Zr}, \mathrm{Hf})$ и некоторых флюидомобильных элементов (Rb, Ba, Th, U, Pb), возрастает La/Yb отношение, несколько уменьшается содержание $\mathrm{TiO}_{2}$. Важно отметить, что титан здесь ведет себя противоположным образом по сравнению с другими высокозарядными элементами. Минералогический состав пород, образующих эти тренды, свидетельствует, что они формируются в условиях повышенной водонасышенности системы и высокой фугитивности кислорода. Это обычные “островодужные" тренды, которые можно было бы интерпретировать как следствие кристаллизационной дифференциации и фракционирования в системе кристаллы-расплав. Однако эти реальные тренды эволюции составов (см. рис. 11а-в) сильно отличаются от тех "виртуальных" трендов, которые образуют остаточные и включенные в минералы стекла (см. рис. 11г, 5а-д). По данным [Наумов и др. 1997], в общем случае (кристаллизационная дифференциация и фракционирование) должно наблюдаться соответствие между валовыми составами породы и составами гомогенезированных расплавных включений из минералов этих пород. Таких соответствий мы здесь не наблюдаем. "Виртуальные" тренды значительно более щелочные - это видно, например, при сравнении трендов 4в и 5а, относящихся к породам и стеклам докальдерной постройки (см. рис. 11г). Правда, небольшая часть точек составов стекол из трахибазальтов докальдерной постройки находится в поле валовых составов. Фракционирование здесь, вероятно, прошло не полностью, а последовательность изменения реальных составов является следствием эволюции флюидно-магматической системы, которая лишь дополнена фракционной дифференциацией. Также более высокой щелочностью отличаются “виртуальные” тренды в минералах из гавайитов, муджиеритов и андезибазальтов (см. рис. 11г, 5г, 5б и 5в), хотя подобный 
тренд в минералах одного из андезибазальтов (обр. 157), напротив, обеднен щелочами (см. рис. 11г, 5д). Нужно отметить, что и валовой состав этих пород также характеризуется пониженной щелочностью, но полного соответствия между реальными и виртуальными трендами здесь также не наблюдается. Следовательно, для рассматриваемых составов Кекукнайского массива мы имеем расхождение трендов, что, скорее, указывает на эманационную, а не кристаллизационную дифференциацию. Интересно, что подобный пример расхождения трендов на примере экструзивных дацитов вулкана Менделеева (о. Кунашир) объясняется именно как результат флюидно-магматической дифференциации [Биндеман, Дубик, 1990]. Поскольку в ходе декомпрессионной эволюции теряется большинство расплаво-мобильных компонентов, но одновременно происходит их накопление во флюидонасыщенной части системы, возникающие при этом тренды названы компенсационными.

Таким образом, здесь мы имеем единую расслоенную флюидно-магматическую систему, с большей ролью флюидов в верхней части и более магматогенную в нижней (как для системы в целом, так и для отдельных ее фрагментов, отражающих дифференциацию системы в промежуточных очагах). Тогда модель образования Кекукнайского массива можно представить в виде конвейера (“эскалатора"), последовательно поставлявшего на поверхность материал этой системы. "Работа" этого “эскалатора", по-видимому, дважды задерживалась в промежуточных очагах, когда обособились дочерние магмы существенно гавайитового или трахибазальтового состава. Относительное "обезвоживание" системы в начальной стадии ареального вулканизма (трахибазальтовая ассоциация), по всей вероятности, связано с экстракцией флюидомобильных компонентов в ходе кальдерообразования, как это было показано в первой части статьи [Колосков и др., 2011]. Возможно, такая ситуация повторилась и в позднюю стадию эволюции системы (образование мини-кальдеры в СВ части рассматриваемого района, о чем также упоминалось в первой части статьи). Роль давления (разноглубинность магматических очагов) как основного фактора, которым определяются различия в составах поднимающихся магм неоднократно подчеркивалось как в отечественной [Колосков, 2006], так и в зарубежной [Whitaker et al., 2006] литературе.

Некоторые минералогические особенности (присутствие разнообразных микровключений оливиновых микродолеритов, оливиновых пироксенитов, ксенокристаллов кварца в пироксеновой оторочке, кислого плагиоклаза с инверсионными зонами, переполненными апостекловатыми микровключениями) в андезибазальтах шлаковых конусов и более раскристаллизованных дайках и некках наводят на мысль о возможном гибридизме или контаминации исходных пород коровым материалом. Попробуем оценить возможную эффективность этих процессов в общем балансе составов пород Кекукнайского массива. Некоторые андезибазальты и муджиериты поздней стадии ареального вулканизма несут эти признаки коровой контаминации, но они и отличаются аномальными составами. В целом же породы ареального вулканизма характеризуются субафировыми, по сути “закалочными” структурами, что свидетельствует о быстрой их кристаллизации. Возникновение закристаллизованных краевых зон в промежуточных камерах, очевидно, могло явиться серьезным препятствием для возникновения больших объемов гибридных пород. Поэтому отмеченные признаки гибридизма, не сопровождающиеся существенным изменением состава пород, могут иметь чисто петрологический интерес.

Модель петрологического “эскалатора” предполагает наличие нижних этажей конструкции. Необходимо, поэтому, решить вопрос о составе родоначальных расплавов. Ни гавайиты, ни, тем более, трахибазальты в составе Кекукнайского массива не являются адекватными мантийным расплавам, хотя имеют мантийные изотопные характеристики [Колосков и др., 2011]. В них отсутствуют мантийные ксенолиты и они характеризуются умеренными содержаниями таких индикаторных элементов как Nb, Ta, Zr, Hf, которые они уже могли потерять на ранних этапах эволюции. Ранее [Колосков и др., 2001] на основании изучения камчатских ксенолитсодержащих вулканитов внутриплитного типа было высказано предположение о том, что родоначальные расплавы для них могли иметь высокотитанистые магнезиальные базанитовые составы. Подобный тип вулканитов с близкими к значениям для пород Кекукнайского массива изотопными характеристиками, но более высокими содержаниями высокозарядных элементов был описан на западе Камчатки в районе горы Хухч [Перепелов и др., 2007]. Нанесенные на диаграммы (см. рис. 11) средние составы этих базанитов располагаются в начале декомпрессионных трендов. Поэтому, можно предположить, что материнские расплавы для породных ассоциаций рассматриваемого массива имели состав, близкий к базанитам горы Хухч.

\section{ЗАКЛЮЧЕНИЕ}

1. Проведено детальное рассмотрение особенностей минералогического состава пород Кекукнайского массива. Использование уже имеющихся и дополнительно выявленных индикаторных возможностей породообразующих минералов позволило восстановить общую картину эволюции магматических расплавов и условия кристаллизации пород Кекукнайского массива (большую 
или меньшую обводненность и окисленность системы).

2. Существенно островодужные или существенно внутриплитные характеристики в составе пород массива проявлены на разных стадиях развития единой флюидно-магматической системы. Эволюция материнской базанитовой магмы была реализована появлением в промежуточных очагах дочерних магм трахибазальтового (докальдерный этап развития системы) или гавайитового (ареальный вулканизм) состава.

3. Декомпрессионная эволюция этих магм и эманационно-магматическая дифференциация расплавов в сочетании с кристаллизационной дифференциацией и привела к образованию всего многообразия пород Кекукнайского массива.

4. Предложена модель флюидно-магматического “эскалатора", в рамках которой выделяются три типа трендов дифференциации:

1) декомпрессионный, развитие которого идет по линии гавайиты-андезибазальты с малой обводненностью и низкой фугитивностью кислорода в начале тренда, но с возрастанием этих параметров при переходе к андезибазальтам шлаковых конусов, либо - в направлении ареальных трахибазальтов в условиях вторичного "обезвоживания” расплавов при экстракции флюидной фазы в период кальдерообразования;

2) компенсационный, который возникает параллельно с первым в условиях большей обводненности системы, идет в направлении гавайитымуджиериты, либо трахибазальты-трахидациты и отражает результат перераспределения компонентов в ходе эманационной, либо эманационно-кристаллизационной дифференциации расплавов;

3) “виртуальные” тренды, образованные расплавными включениями или остаточными стеклами, которые играют важную роль, так как вскрывают реальную картину соотношения роли эманационной и кристаллизационной дифференциации в ходе становления вулканического массива.

Авторы благодарны В.В. Ананьеву за производство некоторых микрозондовых анализов, а также Л.И. Базановой и О.В. Дирксену за предоставление дополнительных материалов по составу пород.

\section{СПИСОК ЛИТЕРАТУРЫ}

Биндеман И.Н., Дубик Ф.Ю. Высококремнекислый остаточный расплав как результат дифференциации (на примере экструзивных дацитов вулкана Менделеева) //ДАН. 1990. Т. 312. № 3. С. 702-706.

Волынеи О.Н., Колосков А.В., Пополитов Э.И. и др. Геохимические особенности оливинов из различных типов четвертичных базальтов Камчатки и Курил в связи с вопросами петрогенезиса // Геохимия. 1975. № 3. C. 412-419.

Волынеи О.Н., Колосков А.В. Плагиоклазы четвертичных эффузивов и малоглубинных интрузивов Камчатки. Новосибирск: Наука, 1976. 135 с.

Гриб Е.Н. Пироксены эффузивно-эксплозивного комплекса Узон-Гейзерной вулкано-тектонической депрессии (Восточная Камчатка) //Вулканология и сейсмология. 1997. № 4. С. 14-35.

Зиновьев В.И. Определение состава плагиоклаза по результатам химических анализов изверженных горных пород // Геология и геофизика. 1964. № 12. С. 140-144. Колосков А.В. Аномальные магматические зоны современных островодужных систем. Корякско-Камчатская вулканическая зона // Геодинамика магматизма и металлогения Востока России. Кн. 1 / Под ред. Ханчука А.И. Владивосток: Дальнаука, 2006. С. 398-417.

Колосков А.В., Пузанков М.Ю., Пирожкова Е.С. Включения ультрамафитов в базальтоидах островных дуг: к проблеме состава и генезиса переходного слоя "коромантийной смеси” в островодужных системах // Геодинамика и вулканизм Курило-Камчатской островодужной системы. Петропавловск-Камчатский: ИВГиГ ДВО РАН,

2001.C. 123-152.

Колосков А.В., Флеров Г.Б., Перепелов А.Б. Этапы эволюции и петрология Кекукнайского вулканического массива как отражение магматизма тыловой зоны Курило-Камчатской островодужной системы. Часть 1. Геологическое положение и геохимический состав вулканических пород // Вулканология и сейсмология. 2011. № 5. С. 17-41.

Мартынов Ю.А,. Чубаров В.М. Пироксены как индикаторы генезиса эоцен-миоценовой контрастной формации вулканогенных образований нижнего Приамурья // Вулканология и сейсмология. 1982. № 5. С. 23346.

Наумов В.Б., Коваленко В.И., Бабанский А.Д. и др. Генезис андезитов по данным изучения расплавных включений в минералах // Петрология. 1997. Т. 5. № 6. C. 654-665.

Перепелов А.Б., Пузанков М.Ю., Иванов А.В. и др. Неогеновые базаниты Западной Камчатки: минералогогеохимические особенности и геодинамическая позиция // Петрология. 2007. Т. 15. № 5. С. 524-546.

Петрографический кодекс / Под ред. Богатикова О.А. и др. СПб.: ВСЕГЕИ, 2009. С. 24-25.

Рингвуд A.E. Состав и петрология мантии Земли. М.: Недра, 1981. 583 с.

Feeley T.C., Dungan M.A. Compositional and dynamic controls on mafic-silicic magma interactions at continental arc volcanoes: evidence from Cordon El Guadal, TataraSan Pedro. // J. Petrology. 1996. V. 37. № 6. P. 1547-1577. Panjasawatwong Y., Danyushevsky L.V., Crawford A. et al. An experimental study of the effect of meltcomposition on plagioclase-melt equilibrium at 5 and 10 kbar: implications for origin of magmatic high-An plagioclase // Contrib. Mineral. Petrol. 1995. V. 118. P. 420-432.

Speidel D.H., Nofriger R.H. P-T-Fo ${ }_{2}$ relations in the system $\mathrm{Fe}-\mathrm{O}-\mathrm{MgO}-\mathrm{SiO}_{2} / /$ Amer. J. Sci. 1968. V. 266. № 5. P. 205-238.

Sun S.S., McDonough W.F. Chemical and isotopic systematic of oceanic basalts // Magmatism in the Ocean Basins 
Geol. Sac. Spes. Publ. / Eds Saunders A.D., Norry M.J. London, 1989. V. 42. P. 313-345.

Volynets O.N. Geochemical Types, Petrology, and Genesis of Late Cenozoic Volcanic Rocks from the Kurile-Kamchatka Island-Arc System //International Geology Review. 1994. V. 36. P. 373-405.

Volynets A., Churikova T., Wörner G. et al. Mafic Late Miocene - Quaternary volcanic rocks in the Kamchatka back arc region: implications for subduction geometry and slab history at the Pacific-Aleutian junction // Contrib. Mineral. Petrol. 2010. V. 159. № 5. P. 659-687.

Whitaker M.L., Nekvasil H., Lindsley D.H. et al. The Role of Pressure in Producing Compositional Diversity in Intraplate Basaltic Magmas // J. Petrology. 2006. V. 48. № 2. P. 366-393.

\title{
The Evolutionary Stages and Petrology of the Kekuknai Volcanic Massif Reflecting the Magmatism in the Backarc Zone of the Kuril-Kamchatka Island Arc System. Part II. Petrologic and Mineralogical Features, Petrogenesis Model
}

\author{
A. V. Koloskov ${ }^{a}$, G. B. Flerov ${ }^{a}$, A. B. Perepelov ${ }^{b}$, I. V. Melekestsev ${ }^{a}$, \\ M. Yu. Puzankov ${ }^{a}$, and T. M. Filosofova ${ }^{a}$ \\ ${ }^{a}$ Institute of Volcanology and Seismology, Far East Branch, Russian Academy of Sciences, \\ Piipa bul'var, 9, Petropavlovsk-Kamchatskii, 683006 Russia \\ e-mail: kolosav@ksnet.ru \\ ${ }^{b}$ Vinogradov Institute of Geochemistry, Siberian Branch, Russian Academy of Sciences, \\ ul. Favorskogo, 1A, Irkutsk, 664033 Russia \\ e-mail: region@igc.irk.ru
}

\begin{abstract}
The Kekuknai massif was formed in the course of tectono-magmatic activity that involved the origin of a shield volcano and a caldera depression with associated emplacement of extrusions that terminated in intense post-caldera areal volcanism. The mineralogical compositions of the massif's rocks have been considered in detail. The use of previously known and newly developed indicator properties of rock-forming minerals allowed the reconstruction of the general picture of the magmatic melt evolution and conditions of rock crystallization (various fluid and water saturation levels, as well as the oxidation state of the system). Essentially island-arc or intraplate characteristics of the massif's rock compositions are found at different stages of development of a single fluid-magmatic system. Decompression evolution of the parent deep-seated basanitic magma occurred via occurrence in intermediate magma chambers of daughter magmas of trachybasalt (pre-caldera stage) or hawaiite (areal volcanism) composition. Subsequent emanate-magmatic differentiation of these melts, combined with crystallization differentiation under changing $\mathrm{P}-\mathrm{T}-\mathrm{f}_{\mathrm{O}_{2}}$ conditions, resulted in the formation of the entire diversity of the Kekuknai rocks.
\end{abstract}

